\title{
Partitioning of ecosystem respiration in a beech forest
}

Brændholt, Andreas; Ibrom, Andreas; Larsen, Klaus Steenberg; Pilegaard, Kim

Published in:

Agricultural and Forest Meteorology

Link to article, DOI:

10.1016/j.agrformet.2018.01.012

Publication date:

2018

Document Version

Peer reviewed version

Link back to DTU Orbit

Citation (APA):

Brændholt, A., Ibrom, A., Larsen, K. S., \& Pilegaard, K. (2018). Partitioning of ecosystem respiration in a beech forest. Agricultural and Forest Meteorology, 252, 88-98. https://doi.org/10.1016/j.agrformet.2018.01.012

\section{General rights}

Copyright and moral rights for the publications made accessible in the public portal are retained by the authors and/or other copyright owners and it is a condition of accessing publications that users recognise and abide by the legal requirements associated with these rights.

- Users may download and print one copy of any publication from the public portal for the purpose of private study or research.

- You may not further distribute the material or use it for any profit-making activity or commercial gain

- You may freely distribute the URL identifying the publication in the public portal

If you believe that this document breaches copyright please contact us providing details, and we will remove access to the work immediately and investigate your claim 


\section{Title}

\section{Partitioning of ecosystem respiration in a beech forest}

4 Andreas Brændholt $^{1 *}$, Andreas Ibrom ${ }^{1}$, Klaus Steenberg Larsen ${ }^{1,2}$ and Kim Pilegaard ${ }^{1}$

$5 \quad{ }^{1}$ DTU Environment, Technical University of Denmark; ${ }^{2}$ Department of Geosciences and Natural 6 Resource Management, University of Copenhagen.

8 *Correspondence author at: Bygning 115, Bygningstorvet, 2800 Kongens Lyngby, Denmark. E9 mail address: andbr@env.dtu.dk

\section{ABSTRACT}

12 Terrestrial ecosystem respiration $\left(R_{\text {eco }}\right)$ represents a major component of the global carbon cycle. It

13 consists of many sub-components, such as aboveground plant respiration and belowground root and 14 microbial respiration, each of which may respond differently to abiotic factors, and thus to global

15 climate change. To correctly predict future carbon cycles in forest ecosystems, $R_{\text {eco }}$ must therefore

16 be partitioned and understood for each of its various components.

17 In this study we used the eddy covariance technique together with manual and automated closed18 chambers to quantify the individual components of $R_{\text {eco }}$ in a temperate beech forest at diel, seasonal

19 and annual time scales. $R_{\text {eco }}$ was measured by eddy covariance while respiration rates from soil, tree 20 stems and isolated coarse tree roots were measured bi-hourly by an automated closed-chamber 21 system. Soil respiration $\left(R_{\text {soil }}\right)$ was measured in intact plots, and heterotrophic $R_{\text {soil }}$ was measured in 22 trenched plots. Tree stem $\left(R_{\text {stem }}\right)$ and coarse root $\left(R_{\text {root }}\right)$ respiration were measured by custom made 23 closed-chambers 
24 We found that the contribution of $R_{\text {stem }}$ to total $R_{\text {eco }}$ varied across the year, by only accounting for 6

\section{$44 \quad 1$ Introduction}

$\%$ of $R_{\text {eco }}$ during winter and $16 \%$ during the summer growing season. In contrast $R_{\text {soil }}$ was approximately half of $R_{e c o}$ during winter (52\%), spring (45\%) and summer (49\%), while the contribution increased to $79 \%$ during autumn.

Based on observed fluxes in the trenched and intact soil plots, we found that autotrophic $R_{\text {soil }}$ accounted for $34 \%$ of $R_{\text {soil }}$ during summer, i.e. a relatively low fractional estimate compared to findings from other studies. It is likely that dead roots were still decomposing in the trenched soil plots thus causing overestimation of heterotrophic $R_{\text {soil }}$.

Diel $R_{\text {stem }}$ and $R_{\text {root }}$ measurements showed a distinct pattern during summer with the highest respiration rates around 13:00-15:00 CET for $R_{\text {stem }}$, and the highest respiration seen from 9:00-15:00 for $R_{\text {root }}$. In contrast, $R_{\text {soil }}$ showed the lowest respiration during daytime with no clear difference in the diel pattern between the intact and trenched soil plots.

Finally, we calculated annual $R_{\text {soil }}$ for different transects, and found that annual $R_{\text {soil }}$ estimated from the previously used transect at the site was underestimated due to $R_{\text {soil }}$ of the transect not being representative for the spatial heterogeneity of $R_{\text {soil }}$ at the site. This highlights the importance of performing a sufficient number of chamber measurements at a site to adequately capture the spatial variation and estimate $R_{\text {soil }}$ correctly.

Keywords: Ecosystem respiration, flux partitioning, eddy covariance, chamber, seasonality

Ecosystem respiration $\left(R_{e c o}\right)$ is, after gross primary productivity (GPP), the second largest flux of $\mathrm{CO}_{2}$ between the biosphere and the atmosphere (Beer et al. 2010; IPCC, 2013). Reco is the sum of respiration from several component of the ecosystem that may respond differently to abiotic factors, 
and thus to global change (Schimel et al., 2001; Valentini et al., 2003). To correctly understand and predict future ecosystem carbon cycles, $R_{e c o}$ must therefore be partitioned into its main subcomponents. For forests, major components are aboveground autotrophic respiration from the leaves, branches and stems of the trees, and belowground by the autotrophic respiration from tree roots and the heterotrophic respiration from soil microbes, which together form the soil respiration $\left(R_{\text {soil }}\right)$ (Hanson et al., 2000; Högberg et al. 2005, Rodeghiero and Cescatti, 2006).

Ecosystem-level net atmospheric exchange of $\mathrm{CO}_{2}$ (NEE) can be measured on a high temporal scale by the eddy covariance method (e.g. Pilegaard et al., 2001; Wofsy et al., 1993). NEE can be partitioned into GPP and $R_{\text {eco, }}$, by various extrapolation methods, one of which uses temperature response functions to extrapolate from measured nighttime respiration rates to estimates of daytime respiration (Reichstein et al., 2005). Whereas eddy covariance provides $R_{\text {eco }}$ on a high temporal scale, it does not provide information on the individual components that make up $R_{\text {eco. }}$ Instead, chamber based methods can be used to measure the $\mathrm{CO}_{2}$ flux from the individual components by enclosing a specific part of the ecosystem in a chamber. Typically, chambers of the closed type are used, where the $\mathrm{CO}_{2}$ flux is calculated based on the near-linear increase in chamber $\mathrm{CO}_{2}$ concentration during the measurement. Chamber-based methods differ from the eddy covariance method by the smaller spatial coverage (Wang et al., 2010). Eddy covariance covers a large footprint area that may be representative for the studied ecosystem (Nagy et al., 2006). $R_{\text {soil }}$, however, often show a high degree of spatial heterogeneity within the footprint area (Knohl et al., 2008; Webster et al., 2008). At eddy covariance sites, $R_{\text {soil }}$ is often determined with manually operated soil chambers (e.g. Wu et al., 2013). To ensure that $R_{\text {soil }}$ measurements are representative for the eddy covariance footprint, a sufficient number of measurements must be performed throughout the footprint (Davidson et al., 2002; Savage et al., 2008). By performing the manual chamber measurements distributed throughout the footprint at regular intervals throughout the year, 
both the seasonal change in $R_{\text {soil }}$ and the spatial difference in $R_{\text {soil }}$ can be captured to give a good estimate of $R_{\text {soil }}$ for the footprint (Savage and Davidson, 2003). However, because of labour intensiveness, manual measurement campaigns rarely capture diel or day to day variability in the fluxes. Automated chamber systems can allow for measurements at much higher temporal resolution, but because of budget constraints usually only a limited number of automated chambers are available causing low spatial coverage of automatic systems. Apart from $R_{\text {soil }}$, measurements of other ecosystem components such as respiration from leaves, branches and tree stems and woody debris lying on the soil surface have been made using both manual and automated chambers (Rodríguez-Calcerrada et al., 2014; Tang et al., 2008; Zhu et al., 2012). As for $R_{\text {soil, }}$ these components can show a high degree of spatial and temporal variability throughout the footprint, thus requiring a sufficient number of chamber measurements to capture this variability.

The diel pattern of $R_{\text {soil }}$ is generally related to soil temperature (Janssens and Pilegard, 2003; Tang et al., 2005). However, differences in substrate input of carbon from photosynthesis to the soil via the roots can vary across the day (Kuzyakov and Gavrichkova, 2010). Diel changes in substrate input from plants may completely or partly decouple $R_{\text {soil }}$ from the diel pattern of soil temperature (Tang et al., 2005). To study the influence of substrate input and the autotrophic contribution from roots to $R_{\text {soil }}$, a trenching can be performed. Here the contribution of roots to $R_{\text {soil }}$ is removed by cutting off any roots in a plot and preventing them to grow back (Baggs, 2006; Bond-Lamberty et al., 2011). This stops autotrophic $R_{\text {soil }}$ and prevents any input of carbon from photosynthesis. However, the roots are left to decay in the plot and the soil water content may increase (Díaz-Pinés et al., 2010). By comparing plots with intact soil to plots with trenched soil, the heterotrophic and autotrophic components of $R_{\text {soil }}$ can be investigated.

The aim of the study was to quantify the $\mathrm{CO}_{2}$ fluxes from various components of a forest ecosystem on an annual, seasonal, daily and diel scale, and to quantify how the contribution to total $R_{\text {eco }}$ of 
heterotrophic and autotrophic $R_{\text {soil }}$ and stem respiration $\left(R_{\text {stem }}\right)$ vary on a seasonal scale. This was achieved by a combination of the eddy covariance method and manual and automated closedchamber techniques.

\section{Materials and Methods}

\subsection{Site description}

Measurements were performed at the Danish ICOS RI site called DK-Sor at $40 \mathrm{~m}$ a.s.1. $\left(55^{\circ} 29^{\prime} 13^{\prime}\right.$ '

$\mathrm{N}, 55^{\circ} 38^{\prime \prime} 45^{\prime}, \mathrm{E}$ ), where eddy covariance measurements of net ecosystem $\mathrm{CO}_{2}$ fluxes have been performed continuously since 1996. The climate is temperate maritime with an annual average precipitation and an annual average temperature of $564 \mathrm{~mm}$ and $8.5^{\circ} \mathrm{C}$, respectively (Pilegaard et al. 2011).

The forest is dominated by European beech (Fagus sylvatica L.) planted in 1921 with small stands of Norway spruce (Picea abies (L.) Karst) and European larch (Larix decidua Mill.) (Wu et al. 2013). The tree stem density is 288 per hectare with an average tree height of $28 \mathrm{~m}$ and an average diameter at breast height (DBH) of $42 \mathrm{~cm}$ in 2010. The main rooting depth is $1 \mathrm{~m}$ (Pilegaard et al. 2011). However, roots are most frequent at a depth of 0-20 cm (Østergård, 2001). The dense canopy has a peak LAI of 5.0 and the average annual canopy cover duration period is 180 days. The understory is poorly developed due to the well-developed canopy, causing a sparsely vegetated forest floor during most of the year, except during spring when wood anemones (Anemone nemorosa L.) are present in part of the forest floor. Depending on the base saturation, the soils are classified as either alfisols or mollisols. The soil carbon pool is $20 \mathrm{~kg} \mathrm{~m}^{-2}$ down to $1 \mathrm{~m}$ depth, with a $\mathrm{C} / \mathrm{N}$ ratio of 20 in the upper organic soil layers, decreasing to 10 in the lower mineral layers (Østergård, 2001). The organic layer is 10-40 cm deep (Pilegaard et al. 2001).

\subsection{Eddy covariance measurements}


120 Measurements of NEE were performed at a height of $43 \mathrm{~m}$ on the flux tower on the site by a closed121 path eddy covariance system based on a Gill HS-50 3D research sonic anemometer (Gill 122 Instruments Limited, Lymington, UK) and a fast response infrared gas analyser LI-7000 (LI-COR 123 Environmental, Lincoln, Nebraska, USA). For details on the raw data processing, see Pilegaard et 124 al. (2011). Nighttime fluxes at insufficient turbulent mixing were removed when the friction 125 velocity $\left(u_{*}\right)$ was lower than $0.1 \mathrm{~m} \mathrm{~s}^{-1}$ and the atmospheric stratification was stable. A dead band of 1262 hours after re-establishment of turbulent conditions was applied to avoid double accounting from 127 measuring $\mathrm{CO}_{2}$ fluxes from venting the canopy air space. The removal of data below the $u_{*}$ 128 threshold value, and periods of system failure, resulted in a data coverage of $54.1 \%$ for 2016 . The 129 data set was gap-filled and NEE was partitioned into GPP and $R_{e c o}$ by the online "REddyProc: Eddy 130 covariance data processing tool" (Department of Biogeochemical Integration, MPI Jena). In short, 131 the gap-filling procedure follows the approach by Reichstein et al. (2005), and the partitioning of 132 NEE follows the look-up table approach by Reichstein et al. (2005) and the regression approach by 133 Lasslop et al. (2010). This resulted in a continuous data set of half-hourly values of NEE, GPP and $134 R_{e c o}$ for the entire year. From the half-hourly values, the mean daily values were calculated as well 135 as monthly and annual sums of NEE, GPP and $R_{e c o}$.

136 For the each of the annual sums of NEE, GPP and $R_{e c o}$ an uncertainty estimate was calculated. Wu 137 et al. (2013) used five years of data to calculate the relative uncertainties of the annual sums of 138 NEE, GPP and $R_{e c o}$ for the DK-Sor site by taking the uncertainties caused by $u_{*}$ filtering, gapfilling 139 and site heterogeneity into account. By using these relative uncertainties, we calculated the 140 uncertainty estimates for the annual sums of NEE, GPP and $R_{e c o}$. 
$R_{\text {soil }}$ was measured manually using a portable $8100-10210 \mathrm{~cm}$ survey chamber connected to a LIbut no living plants. The first transect, called the inside fence transect, consisted of 12 plots that were positioned within $15 \mathrm{~m}$ of the flux tower. The second transect, called the south transect, consisted of 27 plots, which were positioned at 9 locations along a straight line starting $30 \mathrm{~m}$ from the flux tower and ending $270 \mathrm{~m}$ south of the tower. Each of the 9 locations contained $3 R_{\text {soil }}$ plots.

151 The last transect, called the west transect, consisted of 45 plots. The plots were positioned in groups 152 of three at 15 locations along two parallel lines that were separated by 30 meters. The lines started $15330 \mathrm{~m}$ from the flux tower and ended $210 \mathrm{~m}$ to the west. The location for the south and west transects were chosen to be in the main wind directions and source area for the eddy covariance measurement. See Pilegaard et al. (2011) and Wu et al. (2013) for information about the footprint area and wind direction at the site.

The manual measurements were performed at an interval of two to three weeks, where $R_{\text {soil }}$ was measured once per plot with a chamber closure time of 150 seconds. This resulted in 20 campaign measurements evenly distributed in time during 2016 for each of the transects. The measurements of the three transects were typically performed on two adjacent days between 09:00-16:00 CET,

161 with the inside fence and south transect being measured on the first day, and the west transect being 162 measured on the second day.

\subsection{Automated closed-chamber measurements}

165 In addition to the manual chamber measurements, automated closed-chamber measurements of 166 respiration from intact soil, trenched soil, coarse roots and tree stems were performed from 4 

soil, root and stem chambers were positioned within $15 \mathrm{~m}$ from the flux tower. The system performed well through the entire measurement period leading to automatic measurement being 171 performed each day.

$172 R_{\text {soil }}$ was measured by six opaque soil chambers on circular soil collars with a diameter of $20 \mathrm{~cm}$ 173 that were permanently inserted $4 \mathrm{~cm}$ into the soil. The soil collars contained soil and litter but no 174 aboveground plant parts. One of the soil chambers was an 8100-101 Long-Term $\mathrm{CO}_{2}$ flux 175 chambers, and five were 8100-104 Long-Term $\mathrm{CO}_{2}$ flux chambers (LI-COR Environmental, 176 Lincoln, Nebraska, USA). For two of the soil chambers, trenching was first performed on 6 April 1772016 to remove the contribution of living roots to the total $R_{\text {soil }}$ from the plot. The trenching was 178 done by vertically inserting a spade $25 \mathrm{~cm}$ into the soil in a circle around the soil chambers. Roots with a diameter too big to be cut with the spade were cut with a saw. To prevent ingrowth of roots, monthly re-trenching was performed throughout the study period. Thus, the six soil chamber plots 181 consisted of two trenched soil plots and four intact soil plots.

$182 R_{\text {stem }}$ and $R_{\text {root }}$ were measured with two custom made coarse root chambers and two custom made 183 stem chambers, respectively. Unlike the LI-COR soil chambers, the root and stem chambers did not 184 open between measurements. Instead, the chamber headspace was continuously flushed between measurements with atmospheric air that was let into the chamber by a small tube. The flow of air to 186 all root and stem chambers was provided by a pump, and the flow to each chamber set to $1 \mathrm{~L} \mathrm{~min}^{-1}$ 187 by a flow meter. This resulted in a near ambient atmospheric air $\mathrm{CO}_{2}$ concentration in the chambers 188 between measurements. At the beginning of a chamber measurement, the flow of air to the specific 189 chamber was stopped by automatically closing a normally open solenoid valve that was placed on 190 the flush tube going to the chamber. Thus, the chambers were closed during measurements. 
191 The two root chambers were made of transparent acrylic glass and were cylindrical in shape with an 192 inner length of $24 \mathrm{~cm}$ and an inner diameter of $7 \mathrm{~cm}$ giving a volume of $923 \mathrm{~cm}^{3}$. Before assembly 193 the cylinder was cut in two halves in the longitudinal axis. A $10 \mathrm{~cm}$ long tube with an inner 194 diameter of $0.5 \mathrm{~cm}$, and a filter in the end was attached to the chamber, which acted as a vent to the 195 atmosphere. The chambers were installed in June 2015. For each chamber a suitable coarse root 196 from a soil depth of 5-10 cm was carefully exposed, and the root was rinsed by tap water. The 197 diameter of root was measured, and the root volume and root surface area was calculated. The root 198 was placed in the one half of the cylinder and the other half of the cylinder was placed on top. In 199 each end of the cylinder, the root went through a hole. The two half cylinders were sealed to each 200 other and the hole around the root in each end was sealed with Blu-tack. Following this, the 201 chamber was covered with soil.

202 The two stem chambers were cylindrical and made of polypropylene, with an inner diameter of 15 $203 \mathrm{~cm}$ and an inner height of $10 \mathrm{~cm}$, giving a volume of $1757 \mathrm{~cm}^{2}$. A $10 \mathrm{~cm}$ vent tube with an inner 204 diameter of $0.5 \mathrm{~cm}$, and a filter in the end was attached at the bottom of the chamber. The chambers 205 were attached to the smooth stem surfaces of two beech trees at a height of $1.3 \mathrm{~m}$ by a rubber 206 extrusion with a u-profile that was attached to the chamber and sealed with silicone. The chamber 207 was held in place on the stem by adjustable straps.

208 The ten chambers were connected to the LI-8100A/ LI-8150 in a multiplexed setup, and the system 209 was set up in a repeated automated two-hour cycle during which a measurement of each of the soil, 210 root and stem chambers was performed. The chamber closure time was set to 5 minutes and the pre211 purge and post-purge times were set to 40 seconds for all chambers. 
214 All data analysis of the chamber based $\mathrm{CO}_{2}$ fluxes and post-processing of the eddy covariance data 215 was done using $\mathrm{R}$ version 3.2.0 (R Core Team, 2014).

$216 \mathrm{CO}_{2}$ fluxes for all chamber measurements were calculated for each individual measurement on a 217 time and area basis by fitting the non-linear equation by Hutchinson and Mosier (1981) with the 218 nlsLM function (minpack.lm package) for model fitting in R (Elzhov et al. 2015). For the manual 219 chamber measurements, the first 20 seconds after chamber closure were discarded from the flux 220 calculation (the dead band), whereas the dead band was set to 100 seconds for the automated 221 chamber measurements because an external analyser (used in another study) was attached in 222 parallel with the LI-8100/LI-8150 system, causing increased system volume and therefore increased 223 system response time.

224 The calculated automated chamber fluxes from soil, stem and coarse roots were quality flagged first 225 by removing fluxes with an $r^{2}<0.80$ of the fit. Following this, the automated soil fluxes, but not 226 stem and root fluxes, were further quality flagged by removing measurements performed at low $u_{*}$, 227 where soil fluxes measured by the LI-8100A/LI-8150 system at the site have been found to be 228 overestimated (Brændholt et al. 2017). In short, the automated soil chamber fluxes were compared 229 with $u_{*}$ measured at the flux tower. From a plot of the fluxes against $u_{*}$, a threshold value of $0.2 \mathrm{~m}$ $230 \mathrm{~s}^{-1}$ was determined visually, as where the decrease of fluxes in response to an increase in $u *$ levelled 231 off. Fluxes below the $u_{*}$ threshold value were removed from further analysis. In total the quality 232 control removed $16.3 \%$ of the automated root and stem chamber measurements and $44.9 \%$ of the 233 automated soil chamber measurements, leaving 30124 automated chamber measurements for 234 further analysis. For the manual chamber measurements no quality control was applied in the post 235 processing. Instead the quality control was done in the field following a measurement. If the 236 coefficient of variance of the flux, provided by the LI-COR software, was higher than $1.4 \%$, the 237 measurement was discarded and an extra measurement was performed on the plot. 
238 From the quality controlled flux chamber measurements different estimates for the annual $\mathrm{CO}_{2}$ 239 fluxes were calculated for both the manual and automated measurements following the procedure 240 described by Brændholt et al. (2017). For the manual measurements, annual soil $\mathrm{CO}_{2}$ fluxes were 241 calculated both for the inside fence transect, the south transect and the west transect.

242 For each transect, the manual fluxes were used to parameterize an empirical model of $R_{\text {soil }}$ as a 243 function of soil temperature as described by Lloyd and Taylor (1994):

$R_{\mathrm{S}}=R_{283} \exp \left[-E_{0}\left(\frac{1}{T_{\mathrm{S}}+273.15-T_{0}}-\frac{1}{T_{\mathrm{S}}-T_{0}}\right)\right]$,

where $T_{0}$ and $E_{0}$ are fitted parameters, $T_{\mathrm{s}}$ is soil temperature measured at $5 \mathrm{~cm}$ depth and $R_{283}$ is the base respiration at a soil temperature of $10^{\circ} \mathrm{C}$. The model was fitted with nlsLM in the R package minpack.lm (Elzhov et al. 2015) that uses a nonlinear least squares regression based on a Levenberg-Marquardt algorithm. By using soil temperature at $5 \mathrm{~cm}$ depth measured continuously at the site as model driver input, a continuous one-year time series of mean daily $R_{\text {soil }}$ was calculated. A potential soil temperature bias could occur if the soil temperature continuously measured inside the fence at the site, which was used for modelling of the annual $\mathrm{CO}_{2}$ fluxes, systematically differed from the soil temperatures of the manually measured soil respiration plots. However, no systematic soil temperature difference was found, e.g. exemplified by a mean annual soil temperature inside the fence of $8.4{ }^{\circ} \mathrm{C}$ compared to mean annual soil temperatures of 8.7 and $8.2{ }^{\circ} \mathrm{C}$ for the south transect and west transect, respectively. For the automated measurements, annual mean $\mathrm{CO}_{2}$ fluxes were calculated for the four intact soil plots, the two trenched soil plots, the two root plots and the two stem plots, respectively. Each of 260 the annual $\mathrm{CO}_{2}$ fluxes was calculated by first averaging the bi-hourly fluxes on a monthly basis, 261 providing a diel pattern of fluxes for each month. From this, a daily mean flux was calculated on a 
monthly basis at the average of the bi-hourly values. Monthly fluxes were calculated as the sum of 263 the daily soil fluxes in the respective month, and the annual flux was calculated as the sum of the 12 264 months.

265 The uncertainties of the annual soil $\mathrm{CO}_{2}$ fluxes based on the manual chamber for each of the three 266 transects were estimated by the approach used in Wu et al. (2013), which is based on Van Oijen et 267 al., (2005). In short, for each transect a Bayesian calibration was used to quantify the uncertainty of 268 the model predictions, for which a Markov Chain Monte Carlo (MCMC) Metropolis-Hastings 269 random walk algorithm was used. We performed 50000 MCMC iterations from which the prior 270 parameter distributions were sampled. Different annual soil $\mathrm{CO}_{2}$ fluxes were calculated using the 271 estimated posterior parameter distributions, and the standard deviation of the annual soil $\mathrm{CO}_{2}$ fluxes 272 was interpreted as the uncertainty of the annual soil $\mathrm{CO}_{2}$ flux for a given transect.

$273 R_{\text {stem }}$, calculated on a stem surface area, was scaled up to the soil surface area by using site data on 274 tree density, tree height and DBH. The tree height and DBH were measured for 54 beech trees 275 during March 2017. For each of the measured trees, the surface stem area was calculated as the 276 surface area of a cylinder with the measured height and a diameter of 0.71 times the measured 277 DBH. This diameter was derived from a form factor for European beech that describes the 278 relationship between the stem ground area at breast height and the volume of wood contained in the 279 stem and branches above a diameter of $5 \mathrm{~cm}$ (Landesverwaltungsamt Sachsen-Anhalt). The average 280 stem surface area calculated from the sampled trees was multiplied with the tree density of 288 281 stems ha ${ }^{-1}$ to get the stem surface area scaled on a soil surface area. From this the measured $R_{\text {stem }}$ on 282 a stem surface area could be converted to a $\mathrm{CO}_{2}$ flux on a soil surface area.

283 The uncertainties of the annual soil $\mathrm{CO}_{2}$ fluxes for the intact soil, trenched and stem measured by 284 the automated chamber were estimated by formal error propagation that took the uncertainties of the 285 various steps in the calculation of the annual fluxes into account. For the annual stem flux, an extra 
level of uncertainty was included in the calculation that accounted for the uncertainty of the upscaling of the fluxes from stem surface area to soil surface area. For this, we assumed an uncertainty of $30 \%$ in the stem surface area calculated from the measurements of tree height and DBH.

\section{Results}

\subsection{Annual $\mathrm{CO}_{2}$ budgets}

Different annual $\mathrm{CO}_{2}$ budgets were calculated for different components of the forest from both the tower based eddy covariance and the automated and manual closed-chamber measurements.

The gap-filled annual NEE calculated from the eddy covariance measurement at a height at $43 \mathrm{~m}$ on the flux tower was $-391 \pm 63 \mathrm{~g} \mathrm{C} \mathrm{m}^{-2} \mathrm{yr}^{-1}$, and the estimated GPP and $R_{\text {eco }}$ were $2272 \pm 136$ and $1882 \pm 301 \mathrm{~g} \mathrm{C} \mathrm{m}^{-2} \mathrm{yr}^{-1}$, respectively (Fig. 1).

Different estimates of annual $R_{\text {soil }}$ were calculated based on the manual closed-chamber measurements that were used to parameterize the Lloyd and Taylor model (Fig. 1). The lowest annual $R_{\text {soil }}$ of $794 \pm 51 \mathrm{~g} \mathrm{C} \mathrm{m}^{-2} \mathrm{yr}^{-1}$ was found for the inside fence transect, where the plots were positioned within a distance of $15 \mathrm{~m}$ from the eddy flux tower. The annual $R_{\text {soil }}$ from the two transects, with soil plots distributed in the forest, were both higher with an annual $R_{\text {soil }}$ of $1024 \pm 89$ $\mathrm{g} \mathrm{C} \mathrm{m}^{-2} \mathrm{yr}^{-1}$ for the west transect and an annual $R_{\text {soil }}$ of $972 \pm 90 \mathrm{~g} \mathrm{C} \mathrm{m}^{-2} \mathrm{yr}^{-1}$ for the south transect. The average annual $R_{\text {soil }}$ based on the automated closed-chamber measurements every two hours was $597 \pm 93 \mathrm{~g} \mathrm{C} \mathrm{m}^{-2} \mathrm{yr}^{-1}$ for the four automated chambers with intact soil and, while the average annual $R_{\text {soil }}$ for the two automated chambers containing trenched soil was $375 \pm 29 \mathrm{~g} \mathrm{C} \mathrm{m}^{-2} \mathrm{yr}^{-1}$, accounting for $63 \%$ of $R_{\text {soil }}$ for the intact soil plots.

307 The annual up-scaled stem $\mathrm{CO}_{2}$ on a soil surface area basis was $264 \pm 88$ and $191 \pm 64 \mathrm{~g} \mathrm{C} \mathrm{m}^{-2} \mathrm{yr}^{-1}$ 308 for the two automated stem chambers, respectively, resulting in an average of $227 \pm 108 \mathrm{~g} \mathrm{C} \mathrm{m}^{-2} \mathrm{yr}^{-}$ $309{ }^{1}$ (Fig. 1). This was equivalent to $258 \pm 15 \mathrm{~g} \mathrm{C} \mathrm{m}^{-2} \mathrm{yr}^{-1}$ on a stem surface area basis. 
310 Compared to the annual estimate of $R_{e c o}$ from the eddy covariance measurements, the annual $R_{\text {soil }}$ 311 constituted 43, 55 and $52 \%$ from the manually measured inside fence transect, the west transect and

312 the south transect, respectively, while the annual $R_{\text {soil }}$ based in the intact soil plots and trenched soil 313 plots measured automatically constituted 32 and $20 \%$ of $R_{e c o}$, respectively. The average stem $\mathrm{CO}_{2}$ 314 flux constituted $12 \%$ of $R_{\text {eco }}$.

\subsection{Seasonal forest respiration}

$317 R_{\text {eco }}, R_{\text {soil }}$ and $R_{\text {stem }}$ generally followed the same pattern throughout the year with the lowest 318 respiration rates during the cold winter months and the highest rates during the warm summer 319 months (Fig. 2, Fig. 3). However, the individual contribution of $R_{\text {soil }}$ and $R_{\text {stem }}$ to the total $R_{\text {eco }}$ 320 differed between the seasons. $R_{\text {stem }}$ showed a high seasonality in its contribution to the total $R_{\text {eco }}$ 321 contributing only $6 \%$ of $R_{\text {eco }}$ during the winter months of January, February and December. A 322 similar low contribution of $7 \%$ was seen during the spring months of March, April and May. 323 However, during the summer months of June, July and August the contribution of $R_{\text {stem }}$ increased to $32416 \%$. In the autumn months of September, October and November the contribution gradually 325 decreased from $16 \%$ in September to a level of $9 \%$ in November, close to the winter level. The 326 monthly pattern of contribution of $R_{\text {soil }}$ to the total $R_{\text {eco }}$ differed from $R_{\text {stem }}$. Here winter, spring and 327 summer were fairly similar contributing 52,45 and $49 \%$ to $R_{\text {eco }}$, respectively. However, $R_{\text {soil }}$ during 328 the autumn months differed from the rest of the year by contributing $79 \%$ to the total $R_{\text {eco }}$.

$329 R_{\text {root}}$, which was measured for two coarse roots, was not scaled up to the soil surface area because of 330 the various contributions of roots of different sizes to total root respiration. 
333 The annual average $R_{\text {soil }}$ for the two trenched soil plots measured by the automated chambers was

$33463 \%$ of annual average $R_{\text {soil }}$ for the four intact soil plots. However, the trenching was not performed

335 until 5 April 2016. To investigate the effect of the trenching on $R_{\text {soil }}$, we looked at $R_{\text {soil }}$ before and 336 after the trenching. Before the trenching $R_{\text {soil }}$ of the trenched plots was $77 \%$ of the $R_{\text {soil }}$ for the 337 intact soil. However, for the remaining part of the year following the trenching, $R_{\text {soil }}$ for the trenched 338 plots decreased to $61 \%$ of the intact soil plots.

339 The course of $R_{\text {soil }}$ generally followed the same pattern throughout the year for both the intact and 340 trenched soil plots, by following changes in soil temperature (Fig. 3). However, during the months 341 of June, July and August where GPP was highest (Fig. 4), the intact soil plots reached higher levels 342 of $R_{\text {soil }}$ with $R_{\text {soil }}$ of the trenched soil plots only being $51 \%$ of the intact plots. $R_{\text {soil }}$ of one of the 343 intact soil plots differed by showing a rapid increase in $R_{\text {soil }}$ during April and May, but then 344 decreasing again to a level similar to the remaining intact soil plots (Fig. 3). For October, November

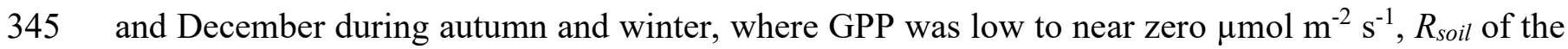
346 intact soil plots decreased to almost the level of the trenched soil plots, with $R_{\text {soil }}$ of the trenched 347 plots being $83 \%$ of the intact plot, a higher level than the pre-trenching level of $77 \%$.

\subsection{Stem respiration and GPP}

350 A rapid increase in GPP was seen in May following the leaf out of the deciduous beech trees (Fig. 351 4). GPP peaked in June and the high GPP continued into July, following by lower GPP in August 352 and September. A similar rapid increase in May was not seen for the two $R_{\text {stem }}$ plots. Instead, a 353 slower increase was seen in May followed by a peak in $R_{\text {stem }}$ in July and August. During autumn, 354 however, the decrease in $R_{\text {stem }}$ did seem to follow the decrease in GPP. Instead of following GPP, 355 the course of $R_{\text {stem }}$ followed the course of $R_{\text {soil }}$ during spring, summer and autumn (Fig. 4). However, 356 during summer a higher day to day variability was seen for $R_{\text {soil }}$ compared to $R_{\text {stem }}$. 

359 The automated chamber measurements performed every two hours throughout the year allowed for 360 investigating the diel patterns of $R_{\text {stem }}, R_{\text {root }}$ and $R_{\text {soil }}$ for both the trenched and intact soil plots for 361 the different seasons of the year (Fig. 5).

362 Although $R_{\text {soil }}$ was higher for the intact soil plots than for the trenched plots, the diel pattern of $R_{\text {soil }}$ 363 generally exhibited the same pattern for both the intact (Fig. 5a, b, c, d) and the trenched soil plots 364 (Fig. 5a, b, c, d). During winter, $R_{\text {soil }}$ was generally higher during daytime than during nighttime. 365 For spring and autumn, however, no clear diel pattern was observed. Summer exhibited a diel 366 pattern with generally low $R_{\text {soil }}$ during daytime. A peak in $R_{\text {soil }}$ was seen early in the morning and 367 late in the evening before midnight. The diel patterns of $R_{\text {stem }}$ and $R_{\text {root }}$ during summer differed from $368 R_{\text {soil }}$ by having the highest respiration rates during daytime (Fig. $\left.5 \mathrm{k}, \mathrm{o}\right) . R_{\text {stem }}$ peaked at 13:00-15:00 369 CET, while a longer peak period from 9:00-15:00 was seen for $R_{\text {root. }}$ For winter and autumn, no diel pattern was seen for $R_{\text {root }}$ (Fig. 5i, 1). However, during spring, a similar diel pattern as during 371 summer with highest $R_{\text {root }}$ during daytime was observed. The diel pattern of $R_{\text {stem }}$ during spring and 372 autumn was similar to the diel pattern during summer, although less pronounced, with highest $R_{\text {stem }}$ 373 during daytime. $R_{\text {stem }}$ for winter, however, showed no diel pattern, which was in contrast to the high 374 daytime $R_{\text {stem }}$ seen during the rest of the year.

375 Soil temperature at $5 \mathrm{~cm}$ depth generally showed no diel pattern during winter, summer and autumn 376 (Fig. 6). During spring, however, a moderate diel pattern was observed with highest soil 377 temperatures late in the afternoon or early in the evening and the lowest soil temperatures in the 378 morning. The difference between the highest and lowest diel temperature was, however, only approximately $1^{\circ} \mathrm{C}$. 


\section{Discussion}

\subsection{Annual $R_{\text {soil }}$ at different transects}

We measured $R_{\text {soil }}$ at three different transects, which revealed that the annual $R_{\text {soil }}$ measured on the inside fence transect was $20 \%$ lower than the average annual $R_{\text {soil }}$ measured on the west and south transects. Manual $R_{\text {soil }}$ measurements on the inside fence transect have previously been used on the site to estimate annual $R_{\text {soil. }}$ Wu et al. 2013 found an average annual $R_{\text {soil }}$ of $752 \pm 30 \mathrm{~g} \mathrm{C} \mathrm{m}^{-2} \mathrm{yr}^{-1}$ for a 5 year period, which is close to the $794 \pm 51$ found in this study. They calculated the aboveground autotrophic respiration to $872 \mathrm{~g} \mathrm{C} \mathrm{m}^{-2} \mathrm{yr}^{-1}$, which they found to be unexpectedly high. They argued that it could be explained if $R_{\text {soil }}$ had been underestimated, due to the plots having lower $R_{\text {soil }}$ than the average $R_{\text {soil }}$ of the footprint. The inside fence transect consisted of 12 plots all positioned within 15 meter of the flux tower, at a relatively dry and high ground. In contrast, the two newly established west and south transects, not used in Wu et al. (2013), consisted of 27 and 45 plots, respectively, that were spread out evenly in the forest. $R_{\text {soil }}$ and soil moisture measured at both transects showed a higher variation than $R_{\text {soil }}$ and soil moisture measured at the inside fence transect (Data not shown). Thus, we argue that the two new transects better represent the spatial variation of $R_{\text {soil }}$ in the eddy covariance footprint than the inside fence transect. The annual $R_{\text {soil }}$ for the two transects were, however, also similar $\left(972 \pm 90\right.$ and $\left.1024 \pm 89 \mathrm{~g} \mathrm{C} \mathrm{m}^{-2} \mathrm{yr}^{-1}\right)$, constituting $53 \%$ of $R_{\text {eco. }}$ Knohl et al. (2008) recommended using at least 8 measurement locations spaced randomly throughout the area of interest to get a representative estimate of $R_{\text {soil }}$ with sufficient confidence. The two new transects contained 9 and 15 locations throughout the eddy covariance footprint, respectively, each location containing 3 soil collars. Thus, measuring $R_{\text {soil }}$ on only one of these transects might be sufficient to cover the spatial variability and get a solid estimation of $R_{\text {soil }}$. The minor difference between the annual $R_{\text {soil }}$ from the two transects also supports this. In contrast, the 
40412 soil collars in the inside fence transect only cover 1 location because they are placed closely 405 together, and therefore do not live up to the recommendations by Knohl et al. (2008).

406 If the new transects had been used in $\mathrm{Wu}$ et al. (2013), the higher $R_{\text {soil }}$ would have changed the 407 extremely high estimate of aboveground autotrophic respiration. If we correct $R_{\text {soil }}$ in $\mathrm{Wu}$ et al. 408 based on the relationship between $R_{\text {soil }}$ of the inside fence transect and the other two transects in this 409 study, then the annual $R_{\text {soil }}$ increases from 752 to $945 \mathrm{C} \mathrm{m}^{-2} \mathrm{yr}^{-1}$. This is turn would lower the 410 estimate of aboveground autotrophic respiration from 872 to $679 \mathrm{~g} \mathrm{C} \mathrm{m}^{-2} \mathrm{yr}^{-1}$, and make the

411 estimates of above and belowground autotrophic respiration more similar as would be expected 412 (Wu et al. 2013).

413 The annual $R_{\text {soil }}$ based on the automated closed-chamber measurements on the 4 intact soil plots was $414597 \pm 93 \mathrm{~g} \mathrm{C} \mathrm{m}^{-2} \mathrm{yr}^{-1}$, lower than annual $R_{\text {soil }}$ of the 3 transects measured by manual chambers. The 415 automated measurements were performed within $15 \mathrm{~m}$ from the flux tower, close to the 12 plots of 416 the inside fence transect. Thus, a somewhat similar annual $R_{\text {soil }}$ could be expected. However, the 417 annual $R_{\text {soil }}$ of the inside transect was $794 \pm 51 \mathrm{~g} \mathrm{C} \mathrm{m}^{-2} \mathrm{yr}^{-1}$, higher than the annual $R_{\text {soil }}$ based on the 418 automated measurements. The cause for the difference in $R_{\text {soil }}$ is unknown. Even though the plots 419 are positioned close to each other, it is possible that spatial heterogeneity within a few metres have 420 caused the difference in $R_{\text {soil }}$. Another possibility is the different closed-chamber systems used, that 421 potentially could lead to different absolute flux values. Lastly, it is possible that the difference 422 between the day time only measurements for the manual chambers and the measurements every two 423 hours for the automated chambers have caused the difference in $R_{\text {soil }}$.

\section{$425 \quad 4.2$ Comparison of annual respiration}

426 GPP was found to be $2272 \pm 136 \mathrm{~g} \mathrm{C} \mathrm{m}^{-2} \mathrm{yr}^{-1}$ (Fig. 1). This is high compared to the average of 1881 $427 \pm 127 \mathrm{~g} \mathrm{C} \mathrm{m}^{-2} \mathrm{yr}^{-1}$ that has previously been found for the site (Wu et al. 2013). We expect an 
optimal growing season during the study period to be part of the reason for this. No summer drought was observed, which has been found to lower forest growth during summer, thus lowering annual GPP (Ciais et al., 2005). The trees could therefore continue to photosynthesize without any

431 edaphic or climatic reduction during summer. Furthermore, September was exceptionally warm, 432 which allowed the trees to continue photosynthesizing for an additional period at high rates (Fig. 4). $433 R_{\text {eco }}$ was found to be high as well at $1882 \pm 301 \mathrm{~g} \mathrm{C} \mathrm{m}^{-2} \mathrm{yr}^{-1}$, which is to be expected due to the 434 commonly found link between GPP and $R_{\text {eco }}$ (Mahecha et al., 2010; Peichl et al., 2013) and higher 435 than the $1624 \pm 201 \mathrm{~g} \mathrm{C} \mathrm{m}^{-2} \mathrm{yr}^{-1}$ found by Wu et al. (2013). Luyssaert et al. (2007) assembled a 436 global database of GPP and $R_{\text {eco }}$ and reported the average GPP and $R_{\text {eco }}$ to be $1375 \pm 56$ and $1048 \pm$ 437 64, respectively, for temperate humid deciduous forests, which is much lower than found for the 438 DK-Sor forest. However, we expect GPP and $R_{e c o}$ for the DK-Sor forest to be higher because the 439 forest is at its main productive phase with a uniform stand of 100 year-old beech trees with high 440 LAI and a fertile soil. Furthermore, the mild maritime climate and the moderately high latitude 441 close to the northern margin of beech forest's geographic range have relatively long days during the 442 vegetation period. With a canopy process model, Ibrom et al. (2006) showed for two different 443 conifer canopies that the northern, maritime climate in Scotland increased the photosynthetically 444 active radiation use efficiency by $13-14 \%$ compared to a more continental climate at a forest site in 445 Central Germany. The reason was longer day lengths, a higher fraction of diffuse radiation and 446 lower vapour pressure deficit at the Scottish site. Compared to the main beech distribution area with 447 many drier and more continental sites, we conclude that the site conditions at the DK-Sor beech 448 forest site allow for comparably high forest productivity.

449 We found an average annual $R_{\text {stem }}$ per unit ground area of $227 \pm 108 \mathrm{~g} \mathrm{C} \mathrm{m}^{-2} \mathrm{yr}^{-1}$, which is the first 450 estimate for this flux component at this site (Fig. 1). The quantification of the $\mathrm{CO}_{2}$ flux from tree 451 stems has not received the same attention as e.g. $R_{\text {soil }}$ and $R_{\text {eco }}$, probably associated with the extra 
work and cost required to construct and operate the custom made stem chambers, and the complications to upscale the measurements to the total stand level. $R_{\text {stem }}$ can, however, be a substantial part of $R_{e c o}$, and constituted $12 \%$ of $R_{e c o}$ in our study. A few studies have addressed the role of $R_{\text {stem }}$ for different forest ecosystems (Ceschia et al., 2002; Edwards and Hanson, 1996; Inoue, 2004; Saveyn et al., 2007; Yang et al., 2015; Zha et al., 2004), and a few studies have looked at $R_{\text {stem }}$ for beech trees (Ceschia et al., 2002; Damesin et al., 2012; Saveyn et al., 2007). Tang et al. (2008) found that $R_{\text {stem }}$ accounted for $13 \%$ of $R_{\text {eco }}$ in a temperate old-growth hardwood forest in the USA, close to the findings for our forest. Damesin et al. (2002) measured respiration from stem and branches and estimated the annual respiration to be between 325 and $383 \mathrm{~g} \mathrm{C} \mathrm{m}^{-2} \mathrm{yr}^{-1}$, with $R_{\text {stem }}$ 461 accounting for approximately $50 \%$. In a review of 18 European forests, Janssens et al. (2000) found 462 that aboveground respiration accounted for $31 \%$ of $R_{e c o}$. If half of the aboveground respiration is 463 accounted for by $R_{\text {stem }}$ as found by Damesin et al. (2002), then $12 \%$ of $R_{\text {eco }}$ accounted for by $R_{\text {stem }}$ in 464 our study is close to the findings by Janssens et al. (2000).

465 Upscaling $R_{\text {stem }}$ from chamber based measurements to soil surface area for comparison with other 466 ecosystem respiration components can cause considerable up-scaling biases. Three main causes of 467 errors can be identified: Insufficient number of measurements in time to catch the temporal 468 resolution in $R_{\text {stem }}$, insufficient number of measurements to catch the spatial variability in $R_{\text {stem }}$ 469 between and within trees, and uncertainty related to scaling up surface measurements to the entire 470 surface of the tree stand. The automatic stem chambers ran continuously throughout the year, thus 471 capturing even the hourly variation of $R_{\text {stem }}$. However, only two stem chambers were available. 472 Annual $R_{\text {stem }}$ between the two were slightly different $\left(264 \pm 88\right.$ and $\left.191 \pm 64 \mathrm{~g} \mathrm{C} \mathrm{m}^{-2} \mathrm{yr}^{-1}\right)$ 473 highlighting the possible variation of $R_{\text {stem }}$ for different trees. We did the measurement at a stem 474 height of $1.3 \mathrm{~m}$. However, it has for some trees been found that stem $\mathrm{CO}_{2}$ flux can vary with stem 475 height (Ceschia et al., 2002). This has been found to be caused by various amounts of $\mathrm{CO}_{2}$ 
dissolved in the xylem that can diffuse out of the stem and therefore contribute to the apparent $\mathrm{CO}_{2}$ flux measured by the chamber (Teskey and McGuire, 2002). Some of this $\mathrm{CO}_{2}$ can be derived from respiration produced elsewhere on the stem, or it can originate from $\mathrm{CO}_{2}$ produced in the soil that is being dissolved in the soil water, taken up by the roots and transported up through the stem (Aubrey and Teskey, 2009; Bloemen et al., 2013; Teskey and Mcguire, 2007). Differences in $R_{\text {stem }}$ along the 481 height of the stems could potentially have influenced the annual estimate of $R_{\text {stem }}$, as well as differences in $R_{\text {stem }}$ between different trees. This was, however, not tested in the current study.

\subsection{Different seasonal contribution of respiration components}

We found a strong seasonal pattern in the contributions of $R_{\text {soil }}$ and $R_{\text {stem }}$ to $R_{\text {eco }}$ (Fig. 2). $R_{\text {eco }}$ generally followed the variation in temperature throughout the year with highest $R_{\text {eco }}$ during the summer growing season. This is usually seen for other temperate forest with growing season during the warm and relatively wet summer (Janssens et al., 2000), in comparison to e.g. Mediterranean ecosystems where $R_{e c o}$ is decoupled from temperature during the hot and dry summers, when water becomes a limiting factor (Matteucci et al., 2015).

The variation in the different seasonal contributions of the individual components to $R_{\text {eco }}$ have been explained by differences in phenology, and their individual response to temperature (Migliavacca et al., 2015). $R_{\text {stem }}$ experienced dramatic differences in the contribution to $R_{\text {eco }}$, with $6 \%$ during winter and $16 \%$ during summer. Although following an overall pattern similar to $R_{\text {soil }}$ (Fig. 4 ), $R_{\text {stem }}$ was much lower during winter. The deciduous beech trees shed their leaves during autumn and enter a

496 dormant period until spring. During this period they do not photosynthesize, and transpiration is 497 limited to a minimum (Essiamah and Eschrich, 1986). Thus the transport through the xylem and 498 phloem is limited to a minimum and respiration is limited to only the necessary maintenance 499 respiration (Damesin, 2003). However, during the growing season growth respiration may be a 
significant part of stem respiration, not directly determined by temperature, but by plant phenology 501 (Lavigne and Ryan, 1997). The difference in $R_{\text {stem }}$ throughout the year may therefore be larger than what can be expected from a general temperature dependence. Our observation of low $R_{\text {stem }}$, both in absolute terms and in its contribution to $R_{e c o}$ during the winter months, fits well with the pattern of tree dormancy during winter, and increased growth respiration during summer. Similar seasonal patterns of $R_{\text {stem }}$ have been found in other temperate forests (Acosta et al., 2008; Edwards et al., 2002; Griffis et al., 2004; Shibistova et al., 2002; Yang et al., 2012, 2014). However, most studies do not measure $R_{\text {stem }}$ during the winter months, making a full comparison difficult.

$R_{\text {soil }}$ from the manual chambers differed dramatically from $R_{\text {stem }}$ by showing a fairly similar contribution to $R_{\text {eco }}$ during both winter, spring and summer of 52, 45 and $49 \%$, respectively, while 510 the contribution increased to $79 \%$ during autumn. Unlike the trees, the microorganisms in the soil 511 do not go into dormancy and can continue to be active and respire, albeit at a slower rate, even 512 during winter (Beverly and Franklin, 2015). Freezing temperatures, which causes the soil to freeze 513 and lower $R_{\text {soil }}$ dramatically can occur at our site. However, the winter period during this study was 514 characterized by above-freezing temperatures during daytime for most of the winter; thereby 515 leaving the entire soil column thawed at most times. The very high contribution of $R_{\text {soil }}$ during autumn coincided with leaf senescence and litterfall. The input of litter to the soil is significant at 517 the site, and has been found to account for $218 \pm 17 \mathrm{~g} \mathrm{C} \mathrm{m}^{-2} \mathrm{yr}^{-1}$ (Wu et al. 2013). Although the rate 518 of $R_{\text {soil }}$ is determined by temperature, the soil organisms will most often respond by increasing $R_{\text {soil }}$ 519 if additional organic matter such as litter is put into the soil (Han et al., 2015). A continuous high $520 R_{\text {soil }}$ or a peak following litterfall has been found for other temperate forest ecosystems (DeForest et 521 al., 2009; Hibbard et al., 2005). Thus, it is likely that the input of litter during autumn has kept $R_{\text {soil }}$ 522 at our site high by fuelling heterotrophic respiration. The trees, however, have shed their leaves and 523 begun to enter dormancy, which lowers the relative contribution of plant respiration to $R_{\text {eco. }}$. 
524 The automated chamber measurements and the trenching revealed information on the contribution 525 of autotrophic $R_{\text {soil }}$ throughout the year. During summer, $R_{\text {soil }}$ of the trenched soil plots was only 51 $526 \%$ of $R_{\text {soil }}$ for the intact plots, while it increased to $83 \%$ during autumn, which was comparable to 527 the pre trenching level of $77 \%$. This indicated that autotrophic $R_{\text {soil }}$ accounted for $49 \%$ during 528 summer. However, before the trenching in April, $R_{\text {soil }}$ of the trenched plots was lower than the intact 529 soil plots, by only accounted for $77 \%$, thus indicating heterogeneous undisturbed $R_{\text {soil }}$. Accounting 530 for this pre trenching difference gives an autotrophic contribution of $34 \%$ during summer.

531 The variation in the seasonal contribution of autotrophic $R_{\text {soil }}$ with highest contribution during the 532 plant growing season was expected and has been observed for several ecosystems (Beverly and 533 Franklin, 2015; Pumpanen et al., 2015; Hanson et al., 2000). The major reason for the seasonal 534 pattern of autotrophic $R_{\text {soil }}$ is the seasonal pattern of GPP that drives an increase in root respiration 535 during the growing season (Pumpanen et al., 2015). Hanson et al. (2000) reviewed the contribution 536 of autotrophic $R_{\text {soil }}$ for different ecosystems and found that the contribution of autotrophic 537 respiration varied from $10 \%$ to more than $90 \%$, with a mean value for forests of $45.8 \% .50 \%$ 538 autotrophic $R_{\text {soil }}$ was found in a mixed beech spruce forest in the south of Germany (Andersen et al., 539 2005). Epron et al., (2001) found a mean autotrophic $R_{\text {soil }}$ of $52 \%$, with highest autotrophic rate of $54060 \%$ in July in a French beech forest. Brumme (1995) found that autotrophic respiration comprised $54140 \%$ in a central German beech forest. Our trenching was performed in April, making a full 542 comparison for the entire year impossible. Our estimate of an autotrophic contribution of $34 \%$ 543 during summer is relatively low compared to prior literature values. However, since the trenching 544 was only performed a few months prior to the measurements, it is possible that decomposing root 545 litter from the severed roots may have contributed to the trenched plots, thereby leading to an 546 overestimated heterotrophic $R_{\text {soil }}$ (Díaz-Pinés et al., 2010; Epron et al., 1999; Hanson et al., 2000; 
Silver et al., 2005; Subke et al., 2006). A second possibility is the presence of deeper living roots 548 below the trenching depth of $25 \mathrm{~cm}$.

549 Instead of following the variation in GPP, $R_{\text {stem }}$ more closely followed $R_{\text {soil }}$ and temperature during 550 spring, summer and autumn (Fig. 4, Fig. 3). Thus the high variation in GPP during the growing 551 season was not seen for $R_{\text {stem }}$, which could indicate that the magnitude of $R_{\text {stem }}$ was independent 552 from the day to day variations in GPP and the associated high respiration rates that are expected for 553 the photosynthesizing organs. The dependence on temperature is in line with other studies that have 554 found a clear temperature dependence of $R_{\text {stem }}$ (Harris et al., 2008; Lavigne et al., 1996; Ryan et al., 555 1995), although photosynthesis has also been found to partially regulate stem respiration (Zha et al., 556 2004).

\subsection{Diel patterns of respiration}

559 Both $R_{\text {stem }}$ and $R_{\text {root }}$ showed a clear diel pattern during summer with the highest respiration seen 560 around 13:00-15:00 CET for $R_{\text {stem }}$, and the highest respiration seen from 9:00-15:00 for $R_{\text {root }}$ (Fig. $5615 \mathrm{o}, \mathrm{k}$ ). The high $R_{\text {stem }}$ during the afternoon is consistent with the findings of other studies (Acosta et 562 al., 2008; Teskey and Mcguire, 2007; Zha et al., 2004). This distinct diel pattern have been 563 explained by a temperature response to the diel pattern of temperature (Teskey and Mcguire, 2007). 564 However, other studies have found diel patterns of $R_{\text {stem }}$ different from the diel pattern of 565 temperature, which has been suggested to be due to the diel pattern of $R_{\text {stem }}$ being modified by 566 photosynthesis and cambium activity independent of temperature (Yang et al., 2014). The diel 567 pattern of $R_{\text {stem }}$ during summer in our study followed the diel pattern of air temperature, thus 568 suggesting that temperature is a main determining factor for $R_{\text {stem }}$ at our site. This is in line with 569 temperature being the determining factor for $R_{\text {stem }}$ at the seasonal scale (Fig. 4, Section 4.3). 570 However, during winter $R_{\text {stem }}$ was very low and showed no diel pattern, which could reflect the tree 
571 dormancy during this period (Fig. 5m). The high $R_{\text {root }}$ during 9:00-15:00 is consistent with the 572 findings of other studies that saw highest $R_{\text {root }}$ during daytime, which often has been found to be 573 linked with photosynthesis (Chen et al., 2010; Drake et al., 2008; Lai et al., 2016; Wertin and 574 Teskey, 2008). During daytime, an increase in $R_{\text {root }}$ is seen due to respiration of recently fixed 575 photosynthates. During nighttime, however, no photosynthesis takes place, leading to the diel 576 pattern in feeding of photosynthates. Photosynthesis at the DK-Sor site usually peaks at noon, 577 before the peak in temperature (Pilegaard et al., 2001). This is consistent with the peak in $R_{\text {root }}$ in 578 this study, thus indicating that photosynthates might in part determine the diel pattern of $R_{\text {root }}$ during 579 summer. Interestingly, no diel pattern was seen during winter and autumn (Fig. 5i, 1). During 580 winter, no photosynthesis takes place, and only little photosynthesis takes place in autumn, thus 581 only a small amount of photosynthates can alter the diel pattern during these periods. During spring, 582 however, a small peak was seen around 15:00 CET, later than the peak seen during summer (Fig. $5835 \mathrm{j}$ ). Spring was the only season that showed a diel pattern of soil temperature at $5 \mathrm{~cm}$ depth (Fig. 584 6b). Thus, it is possible that the temperature response of $R_{\text {root }}$ is dominant during spring.

585 No clear difference in the diel pattern of $R_{\text {soil }}$ was seen between the intact and trenched soil plots 586 (Fig. 5a-h). However, the trenched plots had lower $R_{\text {soil }}$ following the trenching, indicating that the 587 autotrophic contribution to $R_{\text {soil }}$ had been completely or partly removed from the trenched plots 588 (Section 4.3). Heterotrophic $R_{\text {soil }}$ has generally been found to respond to temperature on a seasonal 589 scale, as well as on a diel scale, although a hysteresis on the diel scale between soil temperature and 590 heterotrophic $R_{\text {soil }}$ has also been observed (Chen et al., 2009; Song et al., 2015; Zhang et al., 2015). 591 In contrast, autotrophic $R_{\text {soil }}$ has often been found to be decoupled from temperature on a diel scale, 592 resulting primarily from substrate transfer to the soil bacteria through carbon exudates from plant 593 roots (Kuzyakov and Gavrichkova, 2010). Similarly to the increase in $R_{\text {root }}$ as a result of increased 594 levels of fresh photosynthates, the increase in $R_{\text {soil }}$ has been found to lag after photosynthesis 
595 (Savage et al., 2013; Tang et al., 2005). Whereas we saw an increase in $R_{\text {root }}$ during daytime, we did not see a similar increase in $R_{\text {soil }}$ during daytime in the intact soil plot that contained roots. Instead,

597 a lower daytime $R_{\text {soil }}$ was seen for both the intact and trenched soil plots. Soil temperature at $5 \mathrm{~cm}$ 598 depth generally showed no diel pattern for winter, summer and autumn, which would mean no diel 599 pattern in $R_{\text {soil }}$ if only determined by temperature (Fig. 6). It was surprising that no difference was 600 seen between the intact and trenched soil plots. In a previous study at the site, the diel pattern of $601 R_{\text {soil }}$ was investigated for intact soil (Brændholt et al. 2017). A similar diel pattern with lower 602 daytime $R_{\text {soil }}$ was observed. However, it was found that the measured soil $\mathrm{CO}_{2}$ fluxes were 603 influenced by low atmospheric turbulence, which was found to lead to an overestimation of 604 measured soil $\mathrm{CO}_{2}$ fluxes especially during nighttime, which in turn also biased the diel pattern. In 605 the current study, we removed measurements at low atmospheric turbulence to remove the effect of 606 overestimation of fluxes, as recommended by Brændholt et al. (2017). It is, however, possible that overestimation still plays a role. If this effect is larger than the potential differences in the diel patterns of intact soil and trenched soil, then this effect may overrule the real diel patterns, making it difficult to make a distinction between the diel patterns.

\section{Conclusions}

612 In this study we used the eddy covariance technique together with manual and automated closed613 chambers to quantify the individual components of ecosystem respiration at diel, seasonal and 614 annual scale. We found that the contribution of $R_{\text {stem }}$ to total $R_{\text {eco }}$ varied throughout the year, by only 615 accounting for $6 \%$ of $R_{\text {eco }}$ during winter and $16 \%$ during the summer growing season. In contrast, $616 R_{\text {soil }}$ showed a fairly similar contribution to $R_{\text {eco }}$ during winter, spring and summer of 52,45 and 49 $617 \%$, respectively, while the contribution increased to $79 \%$ during autumn. We attributed the large 618 difference in the seasonal contribution of $R_{\text {stem }}$ to different phenological stages of dormancy and 
619 growth experienced for the trees during the year, whereas we attributed the high contribution of $R_{\text {soil }}$ 620 in autumn to the large input of litter from the deciduous beech trees.

621 By the trenching method, we partitioned $R_{\text {soil }}$ into its heterotrophic and autotrophic components. We 622 found that autotrophic $R_{\text {soil }}$ accounted for $34 \%$ of $R_{\text {soil }}$ during summer, a relative low value 623 compared to findings from other studies. However, we could not rule out the possibility that 624 decomposing roots from the trenched soil plots might have led to an overestimated heterotrophic $625 R_{\text {soil }}$

626 Diel $R_{\text {stem }}$ and $R_{\text {root }}$ showed a clear pattern during summer with the highest respiration seen around 627 13:00-15:00 CET for $R_{\text {stem }}$, and the highest respiration seen from 9:00-15:00 for $R_{\text {root }}$. In contrast, $628 R_{\text {soil }}$ showed the lowest respiration during daytime $R_{\text {soil }}$ with no clear difference in the diel pattern 629 between the intact and trenched soil plots.

630 Finally, we calculated annual $R_{\text {soil }}$ for different transects at the site, and found that annual $R_{\text {soil }}$ 631 estimated from the previously used transect at the site was underestimated due to $R_{\text {soil }}$ of the transect 632 not being representative for the spatial heterogeneity of $R_{\text {soil }}$ at the site. This highlighted the 633 importance of performing a sufficient number of manual chamber measurements at a site to 634 adequately capture the spatial variation in $R_{\text {soil }}$, and thereby to correctly estimate $R_{\text {soil }}$.

\section{Acknowledgements}

637 This study was funded by the Danish Ministry for Research, Innovation and Higher Education, the 638 Danish Council for Independent Research (DFF - 1323-00182). 
641 Acosta, M., Pavelka, M., Pokorný, R., Janouš, D., Marek, M.V., 2008. Seasonal variation in $\mathrm{CO}_{2}$ 642 efflux of stems and branches of Norway spruce trees. Ann. Bot. 101, 469-477.

643 Andersen, C.P., Nikolov, I., Nikolova, P., Matyssek, R., Häberle, K.H., 2005. Estimating "autotrophic" belowground respiration in spruce and beech forests: Decreases following girdling. Eur. J. For. Res. 124, 155-163.

Aubrey, D.P., Teskey, R.O., 2009. Root-derived $\mathrm{CO}_{2}$ efflux via xylem stream rivals soil $\mathrm{CO}_{2}$ efflux. New Phytol. 184, 35-40.

Baggs, E.M., 2006. Partitioning the components of soil respiration: A research challenge. Plant Soil. 284, 1-5.

Beer, C., Reichstein, M., Tomelleri, E., Ciais, P., Jung, M., Carvalhais, N., Rödenbeck, C., Arain, M.A., Baldocchi, D., Bonan, G.B., Bondeau, A., Cescatti, A., Lasslop, G., Lindroth, A., Lomas, M., Luyssaert, S., Margolis, H., Oleson, K.W., Roupsard, O., Veenendaal, E., Viovy, N., Williams, C., Woodward, F.I., Papale, D., 2010. Terrestrial gross carbon dioxide uptake: Global distribution and covariation with climate. Science. 329, 834-838.

Beverly, D., Franklin, S., 2015. Heterotrophic and Autotrophic Soil Respiration under Simulated Dormancy Conditions. Open J. For. 5, 274-286.

Bloemen, J., Mcguire, M.A., Aubrey, D.P., Teskey, R.O., Steppe, K., 2013. Transport of rootrespired $\mathrm{CO}_{2}$ via the transpiration stream affects aboveground carbon assimilation and $\mathrm{CO}_{2}$ efflux in trees. New Phytol. 197, 555-565.

Bond-Lamberty, B., Bronson, D., Bladyka, E., Gower, S.T., 2011. A comparison of trenched plot techniques for partitioning soil respiration. Soil Biol. Biochem. 43, 2108-2114. $\mathrm{CO}_{2}$ effluxes at low atmospheric turbulence. Biogeosciences. 14, 1603-1616. 
664 Brumme, R., 1995. Mechanisms of carbon and nutrient release and retention in beech forest gaps. Plant Soil. 168-169, 593-600.

666 Ceschia, É., Damesin, C., Lebaube, S., Pontailler, J.Y., Dufrêne, É., 2002. Spatial and seasonal variations in stem respiration of beech trees (Fagus sylvatica). Ann. For. Sci. 59, 801-812.

Chen, D., Zhou, L., Rao, X., Lin, Y., Fu, S., 2010. Effects of root diameter and root nitrogen concentration on in situ root respiration among different seasons and tree species. Ecol. Res.

Chen, J.M., Huang, S.E., Ju, W., Gaumont-Guay, D., Black, T.A., 2009. Daily heterotrophic 25, 983-993. respiration model considering the diurnal temperature variability in the soil. J. Geophys. Res. 114, G01022, 1-11.

Ciais, P., Reichstein, M., Viovy, N., Granier, A., Ogée, J., Allard, V., Aubinet, M., Buchmann, N., Bernhofer, C., Carrara, A., Chevallier, F., De Noblet, N., Friend, A.D., Friedlingstein, P., Grünwald, T., Heinesch, B., Keronen, P., Knohl, A., Krinner, G., Loustau, D., Manca, G., Matteucci, G., Miglietta, F., Ourcival, J.M., Papale, D., Pilegaard, K., Rambal, S., Seufert, G., Soussana, J.F., Sanz, M.J., Schulze, E.D., Vesala, T., Valentini, R., 2005. Europe-wide reduction in primary productivity caused by the heat and drought in 2003 . Nature. 437,529 533.

Damesin, C., 2003. Respiration and photosynthesis characteristics of current-year stems of Fagus sylvatica: From the seasonal pattern to an annual balance. New Phytol. 158, 465-475.

Damesin, C., Ceschia, E., Le Goff, N., Ottorini, J.M., Dufrene, E. 2002. Stem and branch respiration of beech: from tree measurements to estimations at the stand level. New Phytol. $153,159-172$.

Davidson, E.A., Savage, K., Verchot, L.V., Navarro, R., 2002. Minimizing artifacts and biases in chamber-based measurements of soil respiration. Agric. For. Meteorol. 113, 21-37. 
DeForest, J.L., Chen, J., McNulty, S.G., 2009. Leaf litter is an important mediator of soil respiration in an oak-dominated forest. Int. J. Biometeorol. 53, 127-134.

Department of Biogeochemical Integration, MPI Jena, 2017. REddyProc: Eddy covariance data processing tool. http://www.bgc-jena.mpg.de/REddyProc/brew/REddyProc.rhtml (accessed 17.05.29).

Díaz-Pinés, E., Schindlbacher, A., Pfever, M., Jandl, R., Zechmeister-Boltenstern, S., Rubio, A., 2010. Root trenching: A useful tool to estimate autotrophic soil respiration? A case study in an austrian mountain forest. Eur. J. For. Res. 129, 101-109.

Drake, J.E., Stoy, P.C., Jackson, R.B., DeLucia, E.H., 2008. Fine-root respiration in a loblolly pine (Pinus taeda L.) forest exposed to elevated $\mathrm{CO}_{2}$ and $\mathrm{N}$ fertilization. Plant, Cell Environ. 31, $1663-1672$.

Edwards, N.T., Hanson, P.J., 1996. Stem respiration in a closed-canopy upland oak forest. Tree Physiol. 16, 433-439.

Edwards, N.T., Tschaplinski, T.J., Norby, R.J., 2002. Stem respiration increases in $\mathrm{CO}_{2}$-enriched sweetgum trees. New Phytol. 155, 239-248.

Elzhov, V.T., Mullen, K.M., Spiess, A., Bolker, B., 2016. minpack.lm: R Interface to the Levenberg-Marquardt Nonlinear Least-Squares Algorithm Found in MINPACK, Plus Support for Bounds, $\mathrm{R}$ package version 1.2-0. http://CRAN.R-project.org/package=minpack.lm (accessed 17.05.29).

Epron, D., Farque, L., Lucot, E., Badot, P.M., 1999. Efflux in a Beech Forest: the Contribution of Root Respiration. Ann. For. Sci. 56, 289-295.

Epron, D., Le Dantec, V., Dufrene, E., Granier, A., 2001. Seasonal dynamics of soil carbon dioxide efflux and simulated rhizosphere respiration in a beech forest. Tree Physiol. 21, 145-152. 
711 Essiamah, S., Eschrich, W., 1986. Water Uptake in Deciduous Trees During Winter and the Role of Conducting Tissues in Spring Reactivation. IAWA Journal. 7, 31-38.

713 Griffis, T.J., Black, T.A., Gaumont-Guay, D., Drewitt, G.B., Nesic, Z., Barr, A.G., Morgenstern, K., Kljun, N., 2004. Seasonal variation and partitioning of ecosystem respiration in a southern boreal aspen forest. Agric. For. Meteorol. 125, 207-223.

Hanson, P.J., Edwards, N.T., Garten, C.T., Andrews, J.A., 2000. Separating root and soil microbial contributions to soil respiration: A review of methods and observations. Biogeochemistry. 48, $115-146$.

Han, T., Huang, W., Liu, J., Zhou, G., Xiao, Y., 2015. Different soil respiration responses to litter manipulation in three subtropical successional forests. Sci. Rep. 5, 18166.

Harris, N.L., Hall, C.A.S., Lugo, A.E., 2008. Estimates of species- and ecosystem-level respiration of woody stems along an elevational gradient in the Luquillo Mountains, Puerto Rico. Ecol. Modell. 216, 253-264.

Hibbard, K.A., Law, B.E., Reichstein, M., Sulzman, J., 2005. An analysis of soil respiration across northern hemisphere temperate ecosystems. Biogeochemistry. 73, 29-70.

Högberg, P., Nordgren, A., Högberg, M.N., Ottosson-Lofvenius, M., Bhupinderpal, S., Olsson, P., Linder, S., 2005. Fractional contributions by autotrophic and heterotrophic respiration to soilsurface $\mathrm{CO}_{2}$ efflux in boreal forests. SEB Exp Biol Ser. 251-267.

Hutchinson, G.L., Mosier, A.R., 1981. Improved soil cover method for field measurement of nitrous oxide fluxes. Soil Sci. Soc. Am. J. 45, 311-316.

Ibrom, A., Jarvis, P.G., Clement, R.B., Morgenstern, K., Oltchev, A., Medlyn, B., Wang, Y.P., Wingate, L., Moncrieff, J., Gravenhorst, G., 2006. A comparative analysis of simulated and observed photosynthetic $\mathrm{CO}_{2}$ uptake in two coniferous forest canopies. Tree Physiol. 26, 845864. 
Inoue, A., 2004. Relationships of stem surface area to other stem dimensions for Japanese cedar (Cryptomeria japonica D. Don) and Japanese cypress (Chamaecyparis obtusa Endl.) trees. J. For. Res. 9, 45-50.

IPCC, 2013. Climate Change 2013: the Physical Science Basis. Contribution of Working Group I to the Fifth Assessment Report of the Intergovernmental Panel on Climate Change. Cambridge University Press, Cambridge, United Kingdom and New York, NY, USA. 1535.

Janssens, I., Pilegard, K., 2003. Large seasonal changes in $Q_{10}$ of soil respiration in a beech forest. Global Biogeochem. Cycles. 9, 911-918.

Janssens, I.A., Lankreijer, H., Matteucci, G., Kowalski, A.S., Buchmann, N., Epron, D., Pilegaard, K., Kutsch, W., Longdoz, B., Grünwald, T., Montagnani, L., Dore, S., Rebmann, C., Moors, E. J., Grelle, A., Rannik, Ü., Morgenstern, K., Oltchev, S., Clement, R., Gudmundsson, J., Minerbi, S., Berbigier, P., Ibrom, A., Moncrieff, J., Aubinet, M., Bernhofer, C., Jensen, N.O., Vesala, T., Granier, A., Schulze, E.D., Lindroth, A., Dolman, A.J., Jarvis, P.G., Ceulemans, R., Valentini, R., 2000. Productivity overshadows temperature in determining soil and ecosystem respiration across European forests. Glob. Chang. Biol. 7, 269-278.

Knohl, A., Søe, A.R.B., Kutsch, W.L., Göckede, M., Buchmann, N., 2008. Representative estimates of soil and ecosystem respiration in an old beech forest. Plant Soil. 302, 189-202.

Kuzyakov, Y., Gavrichkova, O., 2010. Time lag between photosynthesis and carbon dioxide efflux from soil: A review of mechanisms and controls. Glob. Chang. Biol. 16, 3386-3406.

Lai, Z., Lu, S., Zhang, Y., Wu, B., Qin, S., Feng, W., Liu, J., Fa, K., 2016. Diel patterns of fine root respiration in a dryland shrub, measured in situ over different phenological stages. J. For. Res. $21,31-42$.

Landesverwaltungsamt Sachsen-Anhalt, 2011. Leitfaden zur Vorratsermittlung von Waldbeständen und zur Bewertung forstrechtlicher Sachverhalte (In german). https://lvwa.sachsen- 
anhalt.de/fileadmin/Bibliothek/Politik_und_Verwaltung/LVWA/LVwA/Dokumente/pressestell e/publikationen/broschueren/vorratsermittlung.pdf (accessed 17.05.29).

Lasslop, G., Reichstein, M., Papale, D., Richardson, A., Arneth, A., Barr, A., Stoy, P., Wohlfahrt, G., 2010. Separation of net ecosystem exchange into assimilation and respiration using a light

Lavigne, M.B., Franklin, S.E., Hunt Jr, E.R., 1996. Estimating stem maintenance respiration rates of dissimilar balsam fir stands. Tree Physiol. 16, 687-95.

Lavigne, M.B., Ryan, M.G., 1997. Growth and maintenance respiration rates of aspen, black spruce and jack pine stems at northern and southern BOREAS sites. Tree Physiol. 17, 543-551.

Lloyd, J., Taylor, J.A., 1994. On the temperature dependence of soil respiration. Funct. Ecol. 8, $315-323$.

Luyssaert, S., Inglima, I., Jung, M., Richardson, A.D., Reichstein, M., Papale, D., Piao, S.L., Schulze, E.D., Wingate, L., Matteucci, G., Aragao, L., Aubinet, M., Beer, C., Bernhofer, C., Black, K.G., Bonal, D., Bonnefond, J.M., Chambers, J., Ciais, P., Cook, B., Davis, K.J., Dolman, A.J., Gielen, B., Goulden, M., Grace, J., Granier, A., Grelle, A., Griffis, T., Grünwald, T., Guidolotti, G., Hanson, P.J., Harding, R., Hollinger, D.Y., Hutyra, L.R., Kolari, P., Kruijt, B., Kutsch, W., Lagergren, F., Laurila, T., Law, B.E., Le Maire, G., Lindroth, A., Loustau, D., Malhi, Y., Mateus, J., Migliavacca, M., Misson, L., Montagnani, L., Moncrieff, J., Moors, E., Munger, J.W., Nikinmaa, E., Ollinger, S.V., Pita, G., Rebmann, C., Roupsard, O., Saigusa, N., Sanz, M.J., Seufert, G., Sierra, C., Smith, M.L., Tang, J., Valentini, R., Vesala, T., Janssens, I.A., 2007. $\mathrm{CO}_{2}$ balance of boreal, temperate, and tropical forests derived from a global database. Glob. Chang. Biol. 13, 2509-2537.

Mahecha, M.D., Reichstein, M., Carvalhais, N., Lasslop, G., Lange, H., Seneviratne, S.I., Vargas, R., Ammann, C., Arain, M.A., Cescatti, A., Janssens, I.A., Migliavacca, M., Montagnani, L., 
Richardson, A.D., 2010. Global Convergence in the Temperature Sensitivity of Respiration at Ecosystem Level, Science. 329, 838-840.

Matteucci, M., Gruening, C., Goded Ballarin, I., Seufert, G., Cescatti, A., 2015. Components, drivers and temporal dynamics of ecosystem respiration in a Mediterranean pine forest. Soil Biol. Biochem. 88, 224-235.

Migliavacca, M., Reichstein, M., Richardson, A.D., Mahecha, M.D., Cremonese, E., Delpierre, N., 789 Chen, J., Gobron, N., Koffi, E., William Munger, J., Perez-Priego, O., Robustelli, M., Tomelleri, E., Cescatti, A., 2015. Influence of physiological phenology on the seasonal pattern of ecosystem respiration in deciduous forests. Glob. Chang. Biol. 21, 363-376.

Nagy, M.T., Janssens, I.A., Curiel Yuste, J., Carrara, A., Ceulemans, R., 2006. Footprint-adjusted net ecosystem $\mathrm{CO}_{2}$ exchange and carbon balance components of a temperate forest. Agric. For. Meteorol. 139, 344-360.

Østergård, J., 2000. Jordbundsdannelse under bøgeskov og mark ved Lille Bøgeskov, Sorø. Master's thesis, Department of Earth Sciences, University of Aarhus, Denmark, (in Danish).

Peichl, M., Sonnentag, O., Wohlfahrt G., Flanagan, L.B., Baldocchi, D.D., Kiely, G., Galvagno, M., Gianelle, D., Marcolla, B., Pio, C., Migliavacca, M., Jones, M.B., Saunders, M., 2013. Convergence of potential net ecosystem production among contrasting $\mathrm{C}_{3}$ grasslands. Ecology Letters. 16, 502-512.

Pilegaard, K., Hummelshøj, P., Jensen, N.O., Chen, Z., 2001. Two years of continuous $\mathrm{CO}_{2}$ eddyflux measurements over a Danish beech forest. 107, 29-41.

Pilegaard, K., Ibrom, A., Courtney, M.S., Hummelshøj, P., Jensen, N.O., 2011. Increasing net $\mathrm{CO}_{2}$ uptake by a Danish beech forest during the period from 1996 to 2009. Agric. For. Meteorol. 151, 934-946. 
807 Pumpanen, J., Kulmala, L., Lindén, A., Kolari, P., Nikinmaa, E., 2015. Seasonal dynamics of 808 autotrophic respiration in boreal forest soil estimated by continuous chamber measurements. Boreal Environ. Res. 20, 637-650.

R Core Team, 2014. R: A language and environment for statistical computing. R Foundation for Statistical Computing, Vienna, Austria.

Reichstein, M., Falge, E., Baldocchi, D., Papale, D., Aubinet, M., Berbigier, P., Bernhofer, C., 813 Janous, D., Knohl, A., Laurila, T., Lohila, A., Loustau, D., Matteucci, G., Meyers, T., Miglietta, F., Ourcival, J.M., Pumpanen, J., Rambal, S., Rotenberg, E., Sanz, M., Tenhunen, J., Seufert, G., Vaccari, F., Vesala, T., Yakir, D., Valentini, R., 2005. On the separation of net ecosystem exchange into assimilation and ecosystem respiration: Review and improved algorithm. Glob. Chang. Biol. 11, 1424-1439.

Rodeghiero, M., Cescatti, A., 2006. Indirect partitioning of soil respiration in a series of evergreen forest ecosystems. Plant Soil. 284, 7-22.

Rodríguez-Calcerrada, J., Martin-StPaul, N.K., Lempereur, M., Ourcival, J.M., Rey, M. del C. del, Joffre, R., Rambal, S., 2014. Stem $\mathrm{CO}_{2}$ efflux and its contribution to ecosystem $\mathrm{CO}_{2}$ efflux decrease with drought in a Mediterranean forest stand. Agric. For. Meteorol. 195-196, 61-72.

Ryan, M.G., Gower, S.T., Hubbard, R.M., Waring, R.H., Gholz, H.L., Cropper, W.P., Running, S.W., 1995. Woody tissue maintenance respiration of four conifers in contrasting climates. Oecologia. 101, 133-140.

Savage, K., Davidson, E.A., Richardson, D.A., 2008. A conceptual and practical approach to data quality and analysis procedures for high-frequency soil respiration measurements. Funct. Ecol. $22,1000-1007$. 
Savage, K., Davidson, E.A., Tang, J., 2013. Diel patterns of autotrophic and heterotrophic respiration among phenological stages. Glob. Chang. Biol. 19, 1151-1159.

Savage, K.E., Davidson, E.A., 2003. A comparison of manual and automated systems for soil $\mathrm{CO}_{2}$ flux measurements: Trade-offs between spatial and temporal resolution. J. Exp. Bot. 54, 891899.

Saveyn, A., Steppe, K., Lemeur, R., 2007. Daytime depression in tree stem $\mathrm{CO}_{2}$ efflux rates: Is it caused by low stem turgor pressure? Ann. Bot. 99, 477-485.

Schimel, D.S., House, J.I., Hibbard, K.A, Bousquet, P., Ciais, P., Peylin, P., Braswell, B.H., Apps, M.J., Baker, D., Bondeau, A, Canadell, J., Churkina, G., Cramer, W., Denning, A.S., Field, C.B., Friedlingstein, P., Goodale, C., Heimann, M., Houghton, R.A., Melillo, J.M., Moore, B., Murdiyarso, D., Noble, I., Pacala, S.W., Prentice, I.C., Raupach, M.R., Rayner, P.J., Scholes, R.J., Steffen, W.L., Wirth, C., 2001. Recent patterns and mechanisms of carbon exchange by terrestrial ecosystems. Nature. 414, 169-172.

Shibistova, O., Lloyd, J., Zrazhevskaya, G., Arneth, A., Kolle, O., Knohl, A., Astrakhantceva, N., Shijneva, I., Schmerler, J., 2002. Annual ecosystem respiration budget for a Pinus sylvestris stand in central Siberia. Tellus. 54B, 568-589.

Silver, W.L., Thompson, A.W., McGroddy, M.E., Varner, R.K., Dias, J.D., Silva, H., Crill, P.M., Keller, M., 2005. Fine root dynamics and trace gas fluxes in two lowland tropical forest soils. Glob. Chang. Biol. 11, 290-306.

Song, W., Chen, S., Zhou, Y., Wu, B., Zhu, Y., Lu, Q., Lin, G., 2015. Contrasting diel hysteresis between soil autotrophic and heterotrophic respiration in a desert ecosystem under different rainfall scenarios. Sci Rep. 5, 16779.

Subke, J.A., Inglima, I., Cotrufo, M.F., 2006. Trends and methodological impacts in soil $\mathrm{CO}_{2}$ efflux partitioning: A metaanalytical review. Glob. Chang. Biol. 12, 921-943. 
854 Tang, J., Baldocchi, D.D., Xu, L., 2005. Tree photosynthesis modulates soil respiration on a diurnal time scale. Glob. Chang. Biol. 11, 1298-1304.

Tang, J., Bolstad, P.V., Desai, A.R., Martin, J.G., Cook, B.D., Davis, K.J., Carey, E.V., 2008. Ecosystem respiration and its components in an old-growth forest in the Great Lakes region of the United States. Agric. For. Meteorol. 148, 171-185.

Teskey, R.O., McGuire, M.A., 2002. Carbon dioxide transport in xylem causes errors in estimation

Teskey, R.O., Mcguire, M.A., 2007. Measurement of stem respiration of sycamore (Platanus occidentalis L.) trees involves internal and external fluxes of $\mathrm{CO}_{2}$ and possible transport of $\mathrm{CO}_{2}$ from roots. Plant, Cell Environ. 30, 570-579.

Valentini, R., Matteucci, G., Dolman, A.J., Schulze, E.D., Jarvis, P.G., 2003. The carbon sink strength of forests in Europe: a synthesis of results. In: Valentini, R. (Ed.), Fluxes of Carbon, Water and Energy of European Forests, Ecological Studies, vol. 163. Springer, Berlin.

Van Oijen, M., Rougier, J., Smith, R., 2005. Bayesian calibration of process-based forest models: bridging the gap between models and data. Tree Physiol. 25 (7), 915-927.

Wang, M., Guan, D.X., Han, S.J., Wu, J.L., 2010. Comparison of eddy covariance and chamberbased methods for measuring $\mathrm{CO}_{2}$ flux in a temperate mixed forest. Tree Physiol. 30, 149-163.

Webster, K.L., Creed, I.F., Bourbonnière, R.A., Beall, F.D., 2008. Controls on the heterogeneity of soil respiration in a tolerant hardwood forest. J. Geophys. Res. Biogeosciences 113, 1-15.

Wertin, T.M., Teskey, R.O., 2008. Close coupling of whole-plant respiration to net photosynthesis and carbohydrates. Tree Physiol. 28, 1831-40.

Wofsy, S.C., Goulden, M.L., Munger, J.W., Fan, S.M., Bakwin, P.S., Daube, B.C., Bassow, S.L., Bazzaz, F.A., 1993. Net exchange of $\mathrm{CO}_{2}$ in a mid-latitude forest. Science. 260, $1314-1317$. 
Wu, J., Larsen, K.S., van der Linden, L., Beier, C., Pilegaard, K., Ibrom, A., 2013. Synthesis on the carbon budget and cycling in a Danish, temperate deciduous forest. Agric. For. Meteorol. 181, 94-107.

880 Yang, J., He, Y., Aubrey, D.P., Zhuang, Q., Teskey, R.O., 2015. Global patterns and predictors of 881 stem $\mathrm{CO}_{2}$ efflux in forest ecosystems. Glob. Chang. Biol. 22, 1433-1444.

882 Yang, J.Y., Teskey, R.O., Wang, C.K., 2012. Stem $\mathrm{CO}_{2}$ efflux of ten species in temperate forests in 883 Northeastern China. Trees - Struct. Funct. 26, 1225-1235.

884 Yang, Y., Zhao, M., Xu, X., Sun, Z., Yin, G., Piao, S., 2014. Diurnal and seasonal change in stem 885

886 Zha, T., Kellomäki, S., Wang, K.Y., Ryyppö, A., Niinistö, S., 2004. Seasonal and annual stem 887 888 respiration of scots pine trees under boreal conditions. Ann. Bot. 94, 889-896.

Zhang, Q., Katul, G.G., Oren, R., Daly, E., Manzoni, S., Yang, D., Al, Z.E.T., 2015. The hysteresis response of soil $\mathrm{CO}_{2}$ concentration and soil respiration to soil temperature. J. Geophys. Res. Biogeosci. 120, 1605-1618.

Zhu, L.W., Zhao, P., Ni, G.Y., Cao, Q.P., Zhou, C.M., Zeng, X.P., 2012. Individual-and stand-level (8) stem $\mathrm{CO}_{2}$ efflux in a subtropical Schima superba plantation. Biogeosciences. 9, 3729-3737. 


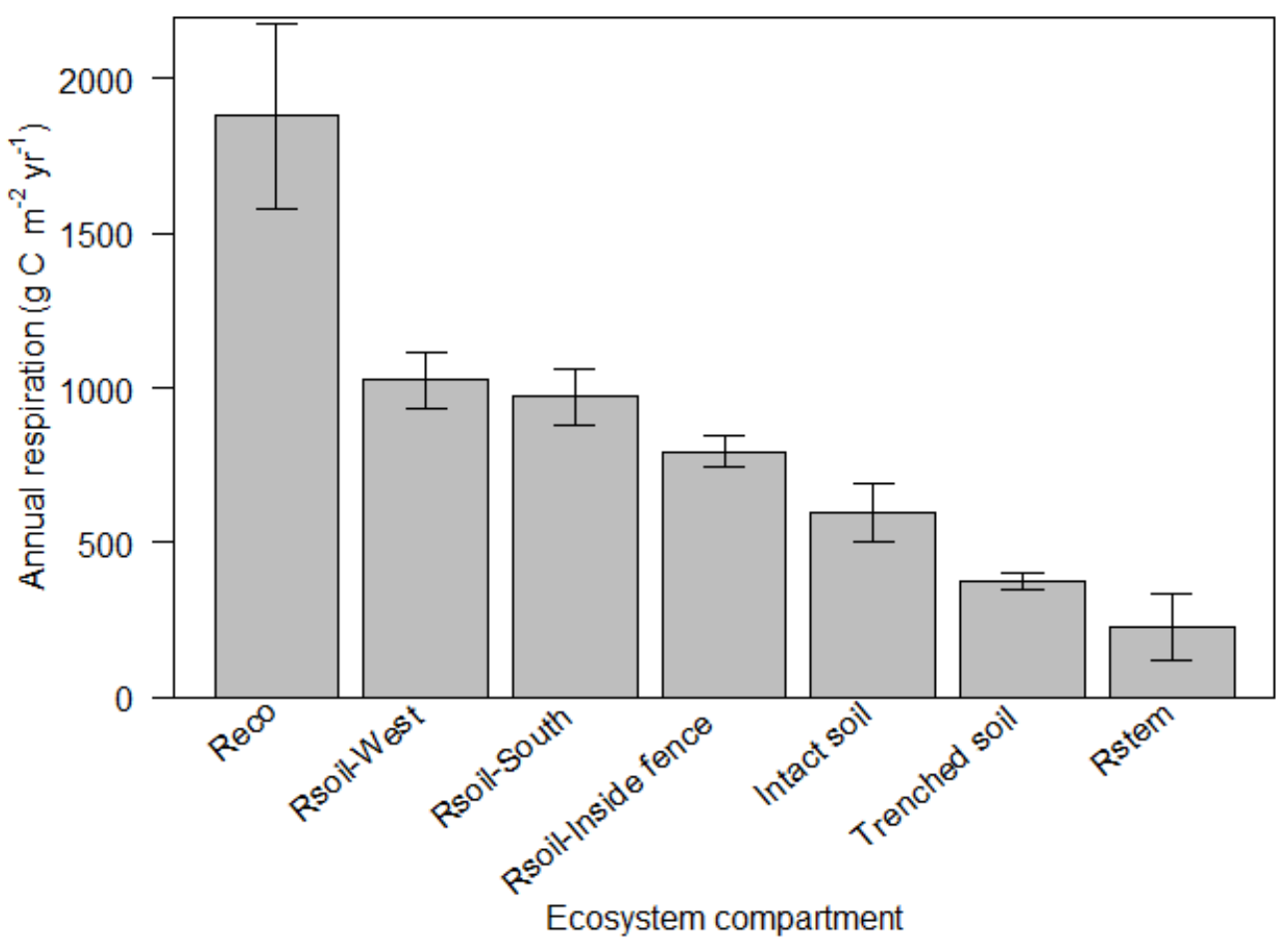

895 Figure 1: Annual respiration for the different components of the ecosystem, with the estimated 896 uncertainties shown by error bars. From left to right the bars show: $R_{\text {eco, }} R_{\text {soil }}$ at the west transect, $897 R_{\text {soil }}$ at the south transect, $R_{\text {soil }}$ at the inside fence transect, $R_{\text {soil }}$ at the intact soil plots measured by 898 the automated chambers, $R_{\text {soil }}$ at the trenched soil plots measured by the automated chambers and $899 R_{\text {stem. }}$ The annual estimated GPP was $2272 \pm 136 \mathrm{~g} \mathrm{C} \mathrm{m}^{-2} \mathrm{yr}^{-1}$. 


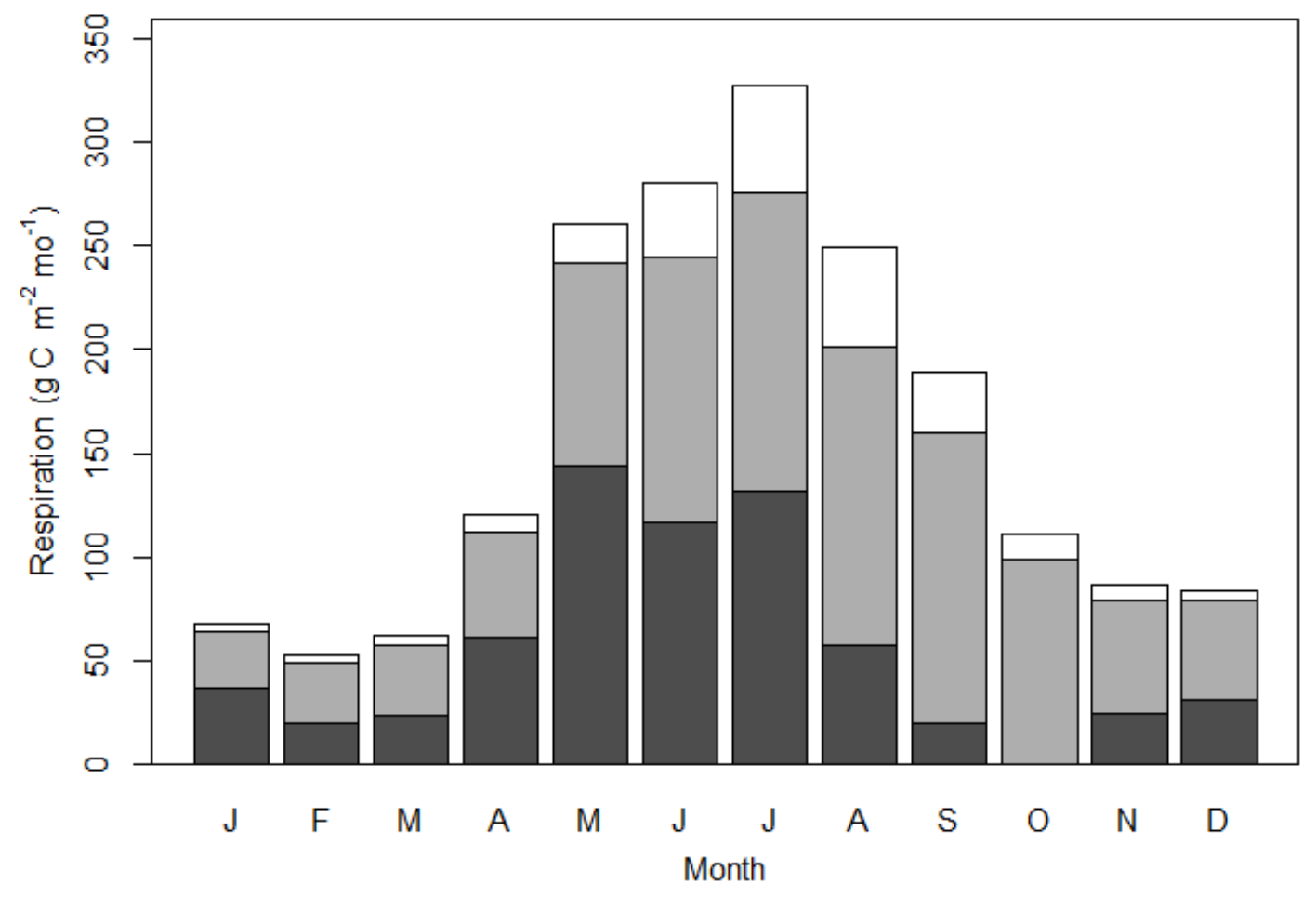

902 Figure 2: $R_{\text {eco }}$ (total bar height) partitioned into the component respiration rates from $R_{\text {soil }}$ (grey) 903 and $R_{\text {stem }}$ (white) on a surface area basis for each month of 2016. The black bars represent the 904 remaining $R_{e c o}$ after $R_{\text {soil }}$ and $R_{\text {stem }}$ have been subtracted, i.e. from tree branches and leaves. For the 905 monthly $R_{\text {soil }}$, the average of the manual closed-chamber measurements of the south and west 906 transect is shown. Note, that for October, $R_{\text {eco }}$ was $11.9 \mathrm{~g} \mathrm{C} \mathrm{m}^{-2} \mathrm{yr}^{-1}$ lower than the sum of $R_{\text {stem }}$ and $907 R_{\text {soil }}$. 


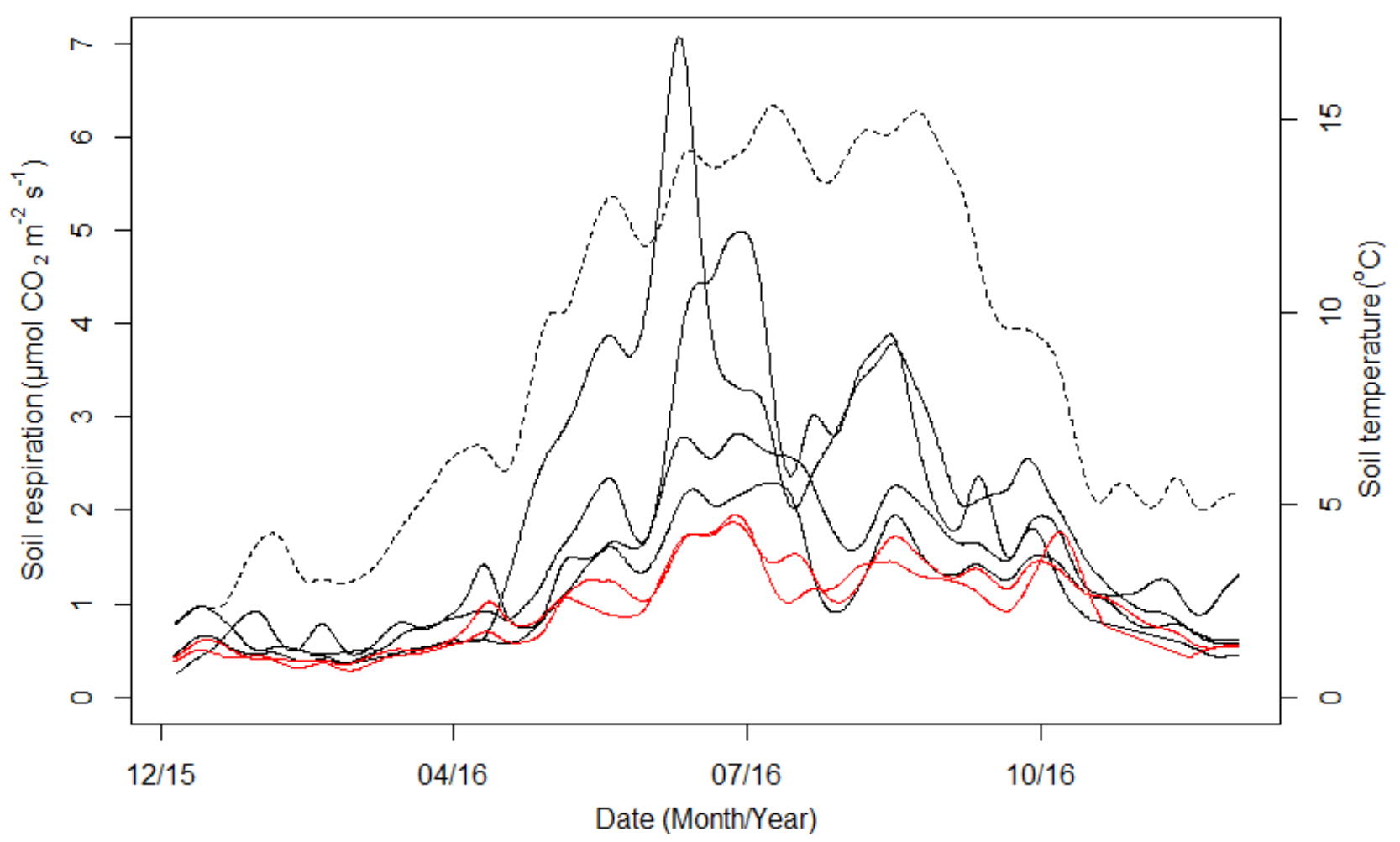

908

909 Figure 3: $R_{\text {soil }}$ (solid lines) throughout the year measured by the automated closed-chambers and 910 soil temperature at $5 \mathrm{~cm}$ depth (dashed line). The black solid lines show the $R_{\text {soil }}$ for the four plots 911 with intact soil and the red solid lines show $R_{\text {soil }}$ for the two plots with trenched soil. The lines have 912 been smoothed to show a running five day average. 


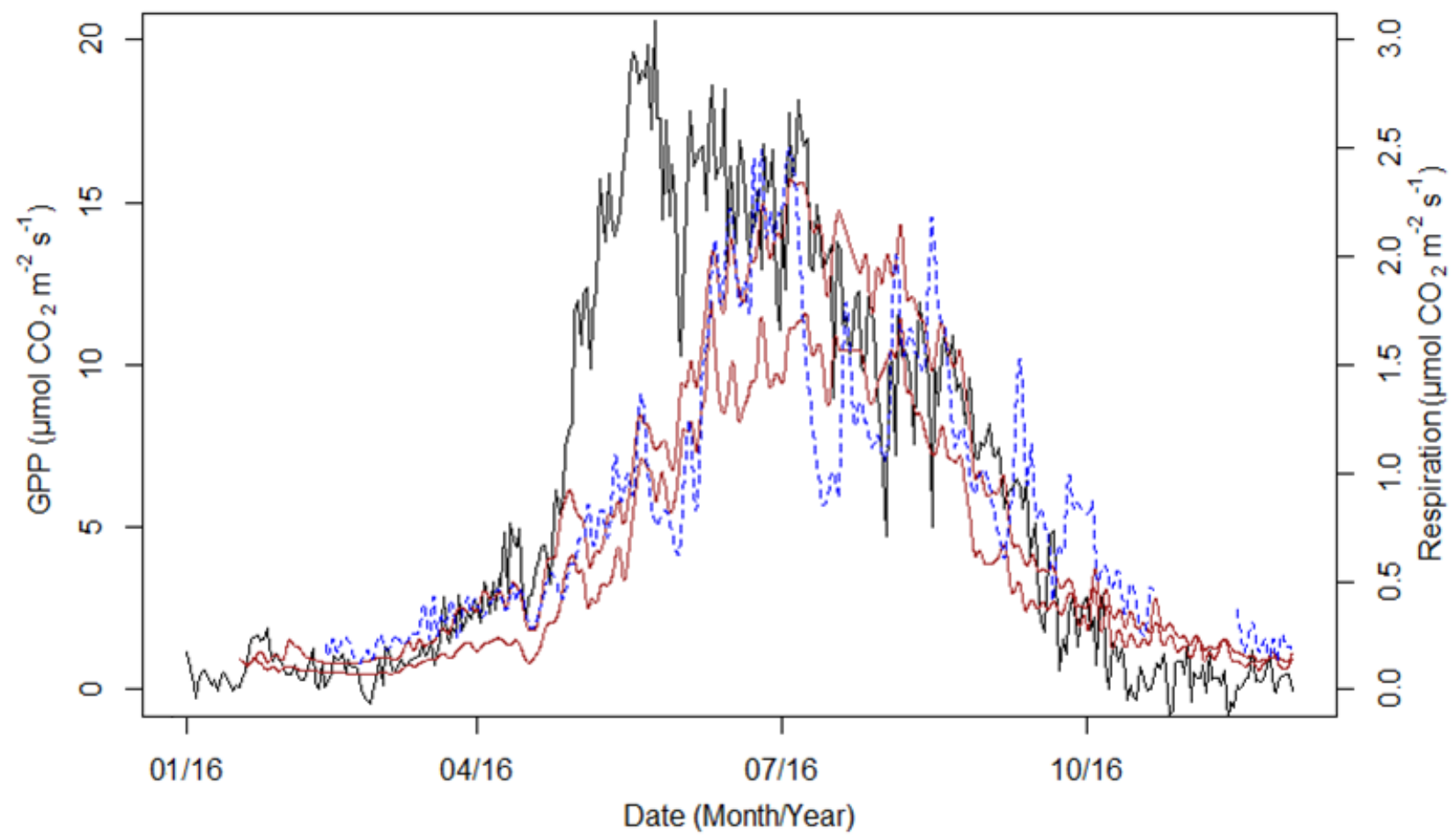

913

$914 \quad$ Figure 4: Mean daily GPP (black line, left y-axis) and $R_{\text {stem }}$ (the red lines, right y-axis) throughout

915 the year. For $R_{\text {stem }}$ both plots are shown. The blue dashed line shows the mean daily $R_{\text {soil }}$ for the

916 intact soil plots measured by the automated closed-chambers. $R_{\text {soil }}$ have been multiplied with 0.45 to 917 fit the right respiration scale. 


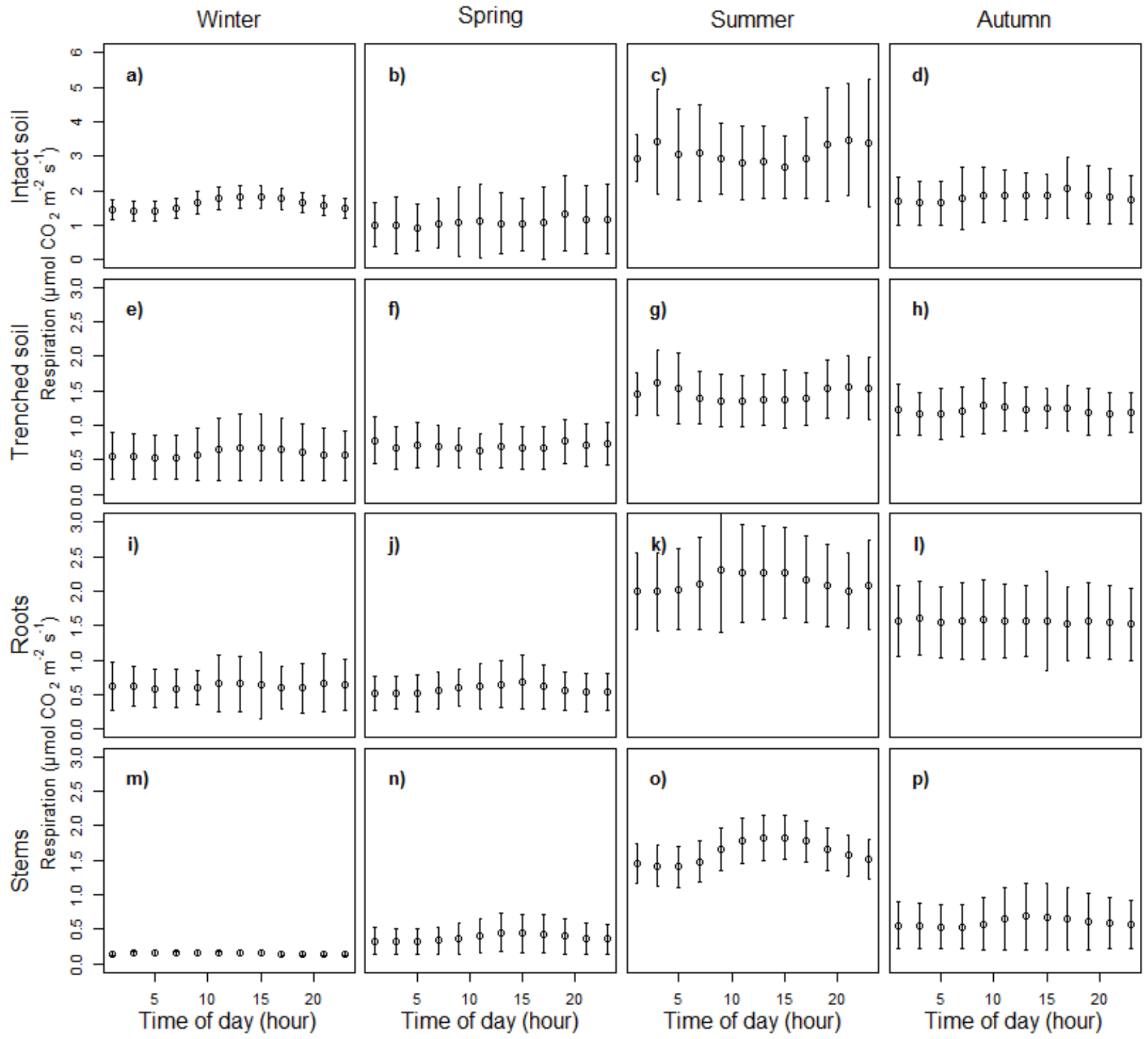

919 Figure 5: Seasonally averaged diel patterns of $R_{\text {soil }}$ for the intact and trenched soil, $R_{\text {root }}$ and $R_{\text {stem }}$ 920 measured by the automated closed-chambers for each of the four seasons. Error bars show standard 921 deviation. The seasons of winter, spring, summer and autumn are shown in the four columns from 922 left to right, respectively. The four rows from top to bottom show $R_{\text {soil }}$ from intact soil, $R_{\text {soil }}$ from 923 trenched soil, $R_{\text {root }}$ and $R_{\text {stem }}$, respectively. $R_{\text {soil }}$ is shown on a soil surface area basis, while $R_{\text {root }}$ and $924 R_{\text {stem }}$ are shown on root surface area and stem surface area basis, respectively. 

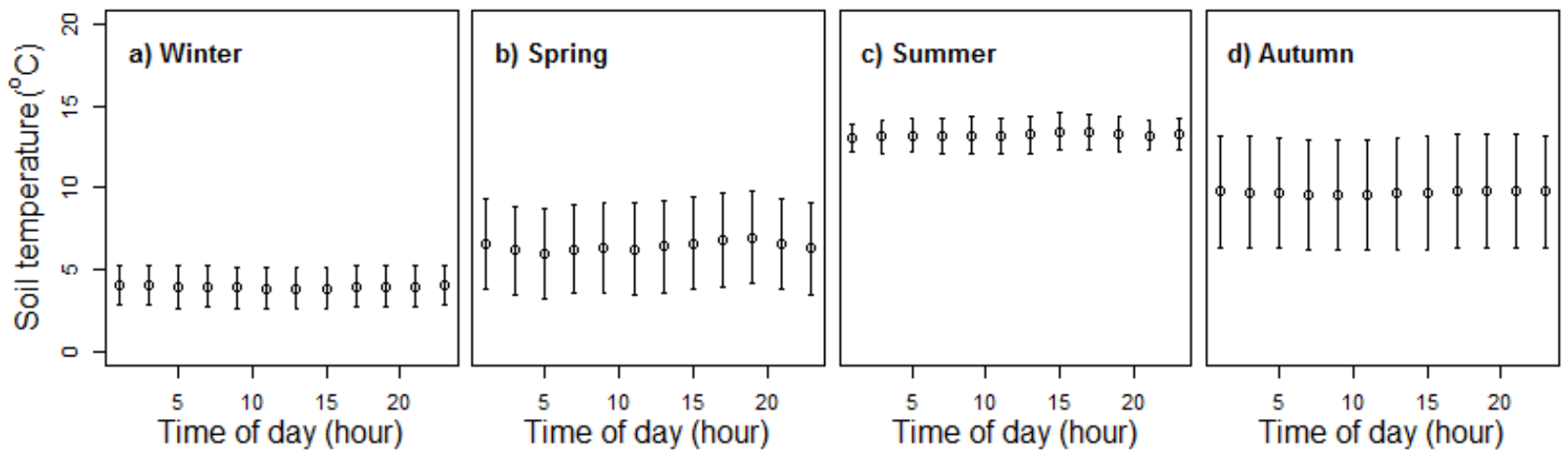

926 Figure 6: Seasonally averaged diel pattern of soil temperature ( \pm standard deviation) at $5 \mathrm{~cm}$ depth

927 measured by soil thermometers installed close to the automated chambers for winter (a), spring (b), 928 summer (c) and autumn (d). 